\title{
Physiological Responses to Nutrient Accumulation in Trees Seedlings Irrigated with Municipal Effluent in Indian Desert
}

\author{
G. Singh, ${ }^{1}$ Madhulika Bhati, ${ }^{1}$ T. R. Rathod, ${ }^{1}$ and U. K. Tomar ${ }^{2}$ \\ ${ }^{1}$ Division of Forest Ecology, Arid Forest Research Institute, New Pali Road, Jodhpur 342005, India \\ ${ }^{2}$ Division of Forest Genetics and Tree Breeding, Arid Forest Research Institute, New Pali Road, Jodhpur 342005, India \\ Correspondence should be addressed to G. Singh; gsingh@icfre.org
}

Received 5 February 2014; Revised 25 June 2014; Accepted 2 July 2014; Published 24 July 2014

Academic Editor: Deyue Yu

Copyright (c) 2014 G. Singh et al. This is an open access article distributed under the Creative Commons Attribution License, which permits unrestricted use, distribution, and reproduction in any medium, provided the original work is properly cited.

Leaf water potential $\left(\Psi_{1}\right)$, net photosynthesis rate $\left(P_{N}\right)$, transpiration rate $(E)$, stomatal conductance $\left(g_{\mathrm{S}}\right)$, and water use efficiency (WUE) are greatly influenced by the nutrient composition of water which is used for irrigating trees. The above-mentioned physiological variables and foliage mineral concentrations were observed for Eucalyptus camaldulensis, Acacia nilotica, and Dalbergia sissoo plants irrigated with municipal effluent (ME) at 1/2 PET (potential evapotranspiration; $\left.\mathrm{T}_{1}\right), 1$ PET $\left(\mathrm{T}_{2}\right)$, and 2 $\operatorname{PET}\left(\mathrm{T}_{3}\right)$ rates and the control plants irrigated with canal water at 1PET $\left(\mathrm{T}_{4}\right)$. Increased mineral concentrations in order $\mathrm{T}_{1}<$ $\mathrm{T}_{2}<\mathrm{T}_{3}$ enhanced $\Psi_{1}, P_{N}, E$, and $g_{S}$. Relatively greater increase in $E$ than $P_{N}$ reduced WUE. Available nutrient in ME enhanced physiological function in $\mathrm{T}_{2}$, whereas reduced quantity of water lowered it in $\mathrm{T}_{1}$ than in $\mathrm{T}_{4}$ plants. Differential minerals uptake increased concentrations of $\mathrm{N}$ and $\mathrm{P}$ in $\mathrm{D}$. sissoo, $\mathrm{Mn}$ in E. camaldulensis, and the rest in A. nilotica. $P_{N}$ was more sensitive to environment than $E$. Enhanced mineral concentration through ME was beneficial but its differential uptake and accumulation influenced physiological functions and WUE. E. camaldulensis is better for high and continuous loading of effluent and A. nilotica is best for high nutrient uptake. D. sissoo is efficient water user.

\section{Introduction}

Land degradation and contamination of environment from a variety of anthropogenic sources such as smelters, power station industry, the application of metal-containing pesticides, fertilizers and sewage sludge are wide spread [1]. Metals/minerals released into environment do not only become irreversibly immobilized in soil components but are also toxic to animals, plants, and microorganisms [2]. Zinc, nickel, and copper are important constituents of pigments and enzymes. Cadmium, lead, mercury, and copper are toxic at high concentrations because of they disrupt enzyme functions, replace essential metals in pigments, or produce reactive oxygen species [3]. Although some plants have tremendous potential to hyperaccumulate minerals $[4,5]$, their excess accumulation could have adverse effect on the physiological functions thereby affecting growth and biomass production of various tree species when exposed to wastewater disposal. The problem is further aggravated due to the prevalence of crosstalk across different elements. Incidents of interaction between phosphorus and other macro-and microelements have been reported in crop species [6], whereas nutrient interactions in $A$. thaliana corroborated the prevalence of crosstalk across $\mathrm{P}$ and $\mathrm{Fe}$ [7]. In addition, Zn deficiency induced accumulation of $\mathrm{P}$ in barley, whereas Pi deficiency in $A$. thaliana resulted in the suppression of high-affinity Zn transporter ZIP9 $[6,8]$. However, the studies pertaining to nutrient interaction have been confined largely to crop species or model plant system.

Unrelenting disposal of effluent of varying chemical constituents is responsible for contamination of land and water bodies, though increased water and nutrients availability by effluent disposal improve photosynthetic capacity of plants [9]. Municipal effluent is a precious resource available in dry regions and is rich in nutrients required for the plants. Rate of photosynthesis, carbon assimilation, and biomass production can be increased in tree by making available this water and nutrients to the nutrient poor soil of the desert region [10]. Though increased photosynthetic efficiency is the most important way of increasing productivity, simultaneous 
increase in mineral concentrations may affect the efficiency of the species towards efficient utilization of this resource [11]. Protective mechanism of plants by absorption and uptake of minerals from the soil reduces soil toxicity and safeguards environment [12]. But long term disposal may lead to excess accumulation of mineral in biological system and affect physiology and productivity [13]. The extent of influences both on the plant and soil needs to be assessed to avoid mineral toxicity during long term effluent application. The influences may be assessed by measuring foliage mineral concentration in and the physiological functions of tree seedlings used in plantation for efficient utilization of the effluent along with environmental and aesthetic benefits.

Present investigation was undertaken to monitor the effect of varying levels of municipal effluent on minerals accumulation in Eucalyptus camaldulensis Dehnh., Acacia nilotica (L.) Willd. ex Delile and Dalbergia sissoo Roxb. ex DC. seedlings, and the physiological responses in these seedlings in relation to the accumulated minerals. Objectives of this study were to monitor changes in physiological functions of tree seedlings influenced by the mineral accumulation due to municipal effluent irrigation/disposal.

\section{Materials and Method}

2.1. Site Description. Experiment was conducted in nonweighing in-filled type of lysimeters of capacity $8 \mathrm{~m}^{3}$ (i.e., size of $2 \mathrm{~m} \times 2 \mathrm{~m} \times 2 \mathrm{~m}$ ) at the experimental field of Arid Forest Research Institute, Jodhpur $\left(26^{\circ} 45^{\prime} \mathrm{N}\right.$ latitude and $72^{\circ} 03^{\prime} \mathrm{E}$ longitude), in Rajasthan, India. The climate of the site is characterized by hot and dry summer, hot rainy season, warm autumn, and cool winter. The mean annual rainfall of 1998, 1999, and 2000 was $420 \mathrm{~mm}$ and the mean annual pan evaporation was $2025 \mathrm{~mm}$. Averages of minimum and maximum air temperatures of a month were $14.5^{\circ} \mathrm{C}$ and $25.0^{\circ} \mathrm{C}$ in January, which increased gradually to $34.4^{\circ} \mathrm{C}$ and $40.7^{\circ} \mathrm{C}$, respectively, in May. The soil was loamy sand (coarse loamy, mixed, hyperthermic family of Typic Camborthides, according to US soil taxonomy) with $82 \%$ sand, $12 \%$ silt, and $6.0 \%$ clay. Soil organic matter was $0.13 \%$ and available $\mathrm{PO}_{4}-\mathrm{P}, \mathrm{NO}_{3}$ $\mathrm{N}$, and $\mathrm{NH}_{4}-\mathrm{N}$ were $5.00,6.00$, and $4.50 \mathrm{mg} \mathrm{kg}^{-1}$, respectively. Soil $\mathrm{pH}$ and electrical conductivity (EC) were 7.61 and 0.71 $\mathrm{dSm}^{-1}$, respectively [14].

2.2. Sampling, Preservation and Analysis of the Effluent. Samples of municipal effluent were collected and analyzed as described earlier $[14,15]$. Samples were analyzed for $\mathrm{pH}$, electrical conductivity, chemical oxygen demand, biochemical oxygen demand, macro- and micronutrients, total dissolved salts, total solids, and total suspended solids [16]. Nitrogen $(\mathrm{N})$ and phosphorus $(\mathrm{P})$ were analyzed following standard procedure [17]. Calcium $(\mathrm{Ca})$, magnesium $(\mathrm{Mg})$, potassium $(\mathrm{K})$, sodium $(\mathrm{Na})$, copper $(\mathrm{Cu})$, iron $(\mathrm{Fe})$, manganese $(\mathrm{Mn})$, and zinc $(\mathrm{Zn})$ were estimated by the aqua-regia method of Jackson [17] followed by a measurement of concentrations using an atomic absorption spectrophotometer (model-3110, Perkin-Elmer, Boesch, Huenenberg, Switzerland). Municipal effluent was alkaline ( $\mathrm{pH} 7.60$ to 8.02); whereas electrical conductivity ranged from 0.91 to $2.14 \mathrm{dSm}^{-1}$ as described earlier [14]. Biochemical and chemical oxygen demand ranged between 36 and $56 \mathrm{mg} \mathrm{L}^{-1}$ and 190 and $270 \mathrm{mg} \mathrm{L}^{-1}$, respectively. Availability of $\mathrm{NH}_{4}-\mathrm{N}, \mathrm{NO}_{3}-\mathrm{N}, \mathrm{PO}_{4}-\mathrm{P}, \mathrm{K}, \mathrm{Fe}$, $\mathrm{Cu}, \mathrm{Mn}$, and $\mathrm{Zn}$ was always higher in municipal effluent than in the canal water. Calcium and iron were highest in concentrations among the basic cations and micronutrients, respectively. The ratios of $\mathrm{K}: \mathrm{N}, \mathrm{K}: \mathrm{Ca}$ and $\mathrm{Mg}, \mathrm{Mg}: \mathrm{Na}$, $\mathrm{Mg}: \mathrm{Mn}, \mathrm{Fe}: \mathrm{Mn}$, and $\mathrm{Zn}: \mathrm{Mn}$ in municipal effluent were $0.04,0.21,0.31,0.91,9.09$, and 1.22, respectively (see Supplementary Table $1 \mathrm{in}$ Supplementary Material available online at http://dx.doi.org/10.1155/2014/545967). These effluent parameters increased during summer (due to high temperature and concentration) and decreased during rainy season (because of addition of runoff water), but highest concentration of $\mathrm{NO}_{3}$ $\mathrm{N}$ during monsoon was due to its addition from the suburban area and the fertilized field through runoff water [14].

\subsection{Plantation and Experimental Design. Nursery raised one-} year-old seedlings of Acacia nilotica, Dalbergia sissoo, and Eucalyptus camaldulensis from a single provenance were planted in July 1998 in the lysimeters of $2 \times 2 \times 2 \mathrm{~m}^{3}$ capacity, which were filled with soil up to $185 \mathrm{~cm}$ leaving $15 \mathrm{~cm}$ space for irrigation. There was one seedling in each lysimeter. The plantation was done in completely randomized design with three replications. Irrigation with municipal effluent was initiated in the first week of September 1998 after seedling establishment. Irrigation was based on the potential evapotranspiration (PET) calculated by multiplication of pan evaporation (Class A evaporation pan fixed at the site) rate and pan coefficient (i.e., 0.70) considering the crop coefficient value of 1.2 to 1.5 for Eucalyptus/Alfaalfa [18-21]. Water uses by tree plantation was considered not less than 1.5 times that of agriculture crop or about 1.25 times of Class A pan [22]. Four treatments comprised $\mathrm{T}_{1}$ : irrigation of seedlings with municipal effluent at $1 / 2$ PET; $\mathrm{T}_{2}$ : irrigation of seedlings with municipal effluent at $1 \mathrm{PET} ; \mathrm{T}_{3}$ : irrigation of seedlings with municipal effluent at 2 PET, and $\mathrm{T}_{4}$ : irrigation of seedlings with canal water (potable water with low mineral concentration) at $1 \mathrm{PET}$ as control. At the time of treatment application, average seedling heights and collar diameters (12 plants) were $37.3 \pm 0.5$ (mean $\pm \mathrm{SE}$ ) $\mathrm{cm}$ and $0.5 \pm 0.0 \mathrm{~cm}$ in E. camaldulensis, $37.8 \pm 2.1 \mathrm{~cm}$ and $0.5 \pm 0.1 \mathrm{~cm}$ in A. nilotica and $49.8 \pm 0.3 \mathrm{~cm}$, and $0.5 \pm 0.0 \mathrm{~cm}$ in $D$. sissoo, respectively.

2.4. Observation Recording. Leaf water potential (LWP) was measured monthly on leaf discs in a leaf chamber (L-52; Wescor, Logan, Utah, USA) connected to a dew point microvoltmeter (Wescor HR-33T) between 0500 and $0700 \mathrm{hr}$ from December 1998 to November 1999 before the reirrigation of the seedlings in each treatment. Leaf disc of $0.5 \mathrm{~cm}$ diameter was punched out from the attached leaves (without leaf abrasion) and was transferred into a leaf chamber and after 15 minutes of equilibration the water potential was determined [23]. The discs were collected at the time of observation recording for each measurement. Net photosynthetic rate $\left(P_{N}\right)$, transpiration rate $(E)$, and stomatal resistance $(R)$ were recorded with open system of portable $\mathrm{CO}_{2}$ Gas 
Analyzer, Model CI-301 (CT-301 PS0), CID Inc., Vancouver, USA. Stomatal conductance $\left(g_{\mathrm{S}}\right)$ was calculated as $1 /$ stomatal resistance. These physiological variables were recorded between 10:00 and 11:00 hrs and at one-month interval from December 1998 to November 2000 (24 months). All these observations were recorded on leaves of middle canopy of the seedlings in three replicates. Self-shading within the cuvette was minimised by ensuring that the leaves did not overlap. Instantaneous water use efficiency (WUE) was calculated as $P_{N} / E$. Atmospheric $\mathrm{CO}_{2}$ concentration during the experiment period was $380 \mathrm{ppm}$.

2.5. Mineral Nutrient Analysis. Irrigation quality criteria of municipal effluent and canal water were assessed as described earlier $[14,15]$. Leaf samples from the 24-month-old planted seedling were collected in June 2000, washed with tap water, and then rinsed with distilled water. The leaf samples were then oven-dried at $80^{\circ} \mathrm{C}$, ground in a palvnizer, and digested with triacid mixture $\left(\mathrm{HNO}_{3}: \mathrm{H}_{2} \mathrm{SO}_{4}: \mathrm{HClO}_{4}\right.$ in $10: 4: 1$ ratio). Concentration of $\mathrm{K}, \mathrm{Ca}, \mathrm{Mg}, \mathrm{Na}, \mathrm{Cu}, \mathrm{Fe}, \mathrm{Mn}$, and $\mathrm{Zn}$ was determined using atomic absorption spectrophotometer [17]. Measurement of $\mathrm{N}$ and $\mathrm{P}$ content was performed after wet digestion with $12 \mathrm{~mL} \mathrm{H}_{2} \mathrm{SO}_{4}$ and two Kjeltab $(\mathrm{Cu} / 3.5)$ catalyst tablets at $350^{\circ} \mathrm{C}$ for half an hour and estimated using UV-VIS spectrophotometer model 117 at 490 and $420 \mathrm{~nm}$ wavelengths, respectively [17].

2.6. Statistical Analysis. Data were statistically analyzed using SPSS statistical package. There were three species and four treatments; hence, the foliage nutrient data were analysed using a two way ANOVA. Tree species and treatments were the factors. Since the physiological data were recorded repeatedly at one-month interval, these data were analysed using repeated measure ANOVA. Physiological parameters per month were the response variables. Month was the within subject factor and tree species and treatments were the between subject factors. Before analysis, average data of these variables were $\log$ or reciprocal of square root transformed for normality [24] and homocedasticity [25] in order to make valid statistical inferences about population relationships. Duncan Multiple Range Tests (DMRT) were also performed on each set of data for homogeneous subsetting for treatments and species. Pearson's correlation was performed to monitor the relations of foliage nutrients concentrations with the physiological variables and total effluent applied. Regressions were performed to observed relations between 24 months average physiological parameters and foliage mineral concentrations.

\section{Results}

3.1. Environmental Factors. Rainfall was $588.5 \mathrm{~mm}$ and total pan evaporation was $5420 \mathrm{~mm}$ during December 1998 to November 2000 showing high water deficit. Air temperature, photosynthetically active radiation (PAR), and vapour pressure deficit (VPD) varied between the months (Figure 1). Averages of minimum and maximum air temperatures of a month increased from the lowest at $08: 00 \mathrm{hr}$ to the highest

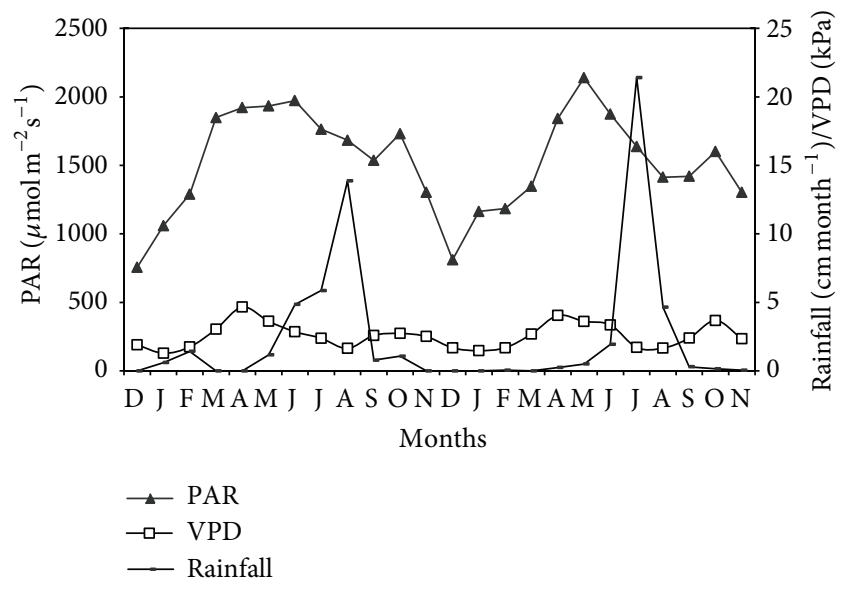

FIGURE 1: Monthly changes in environmental variables. (a) Rainfall, (b) vapour pressure deficit (VPD), and (c) photosynthetically active radiations (PAR).

at 13:00 hr and decreased in the evening (17:00 hr). Vapour pressure deficit (VPD) increased from $1290 \mathrm{~Pa}$ in January, 1999, to $4660 \mathrm{~Pa}$ in April, 1999. PAR was highest at midday (13:00) and oscillated between $811 \mu \mathrm{mol} \mathrm{m}^{-2} \mathrm{~s}^{-1}$ in December, 1999, to $2140 \mu \mathrm{mol} \mathrm{m}^{-2} \mathrm{~s}^{-1}$ in May, 2000 (Figure 1).

3.2. Foliage Nutrient Concentrations. Seedlings irrigated with municipal effluent at $\mathrm{T}_{2}$ and $\mathrm{T}_{3}$ levels had higher $(P<0.05)$ concentration of $\mathrm{N}, \mathrm{P}, \mathrm{K}, \mathrm{Ca}, \mathrm{Mg}, \mathrm{Cu}, \mathrm{Fe}, \mathrm{Mn}$, and $\mathrm{Zn}$ than in the canal water $\left(\mathrm{T}_{4}\right)$ irrigated seedlings across the species (Table 1). Uptake and accumulation of the abovementioned nutrients increased $(P<0.01)$ with irrigation quantity from $T_{1}$ to $T_{3}$. When $T_{1}$ and $T_{4}$ treatments were compared, concentration of $\mathrm{Na}$ in all the species, $\mathrm{Ca}$ and $\mathrm{Mg}$ in E. camaldulensis and $\mathrm{K}$ in D. sissoo seedlings were the lowest in $\mathrm{T}_{1}$, whereas other nutrients were the lowest in the seedlings of $\mathrm{T}_{4}$ treatment. Concentrations of $\mathrm{K}, \mathrm{Ca}, \mathrm{Mg}, \mathrm{Cu}$, and Mn did not differ $(P>0.05)$ between the seedlings of $\mathrm{T}_{1}$ and $\mathrm{T}_{4}$ treatments (DMRT) despite of twofold water applied in latter than in the former treatment (Supplementary Table 2). There was $2 \%\left(\mathrm{Mg}\right.$ in $\left.\mathrm{T}_{1}\right)$ to 2.9 -fold $\left(\mathrm{Mn}\right.$ in $\left.\mathrm{T}_{3}\right)$ increase in nutrient concentration in ME irrigated seedlings than the respective concentrations in the seedlings of $T_{4}$ treatment (Supplementary Table 2). Across the treatments, the concentrations of $\mathrm{K}, \mathrm{Ca}, \mathrm{Mg}, \mathrm{Na}, \mathrm{Fe}, \mathrm{Cu}$, and $\mathrm{Zn}$ were the highest $(P<0.05)$ in $A$. nilotica, $\mathrm{N}$ and $\mathrm{P}$ were the highest in $D$. sissoo and $\mathrm{Mn}$ was the highest in E. camaldulensis seedlings. We observed nonsignificant differences in $\mathrm{Ca}$ and $\mathrm{Cu}$ concentrations between E. camaldulensis and $D$. sissoo and in Mn concentration between A. nilotica and D. sissoo (DMRT). The concentrations of these nutrients were adequate to high $(\mathrm{N}, \mathrm{Ca}, \mathrm{Mg}, \mathrm{Cu}$, and $\mathrm{Fe}$ in E. camaldulensis, $\mathrm{Mg}, \mathrm{K}, \mathrm{Fe}, \mathrm{Zn}$, and $\mathrm{Cu}$ in A. nilotica, and $\mathrm{P}, \mathrm{Ca}, \mathrm{Cu}, \mathrm{Fe}$, and $\mathrm{Zn}$ in D. sissoo) except in treatment $\mathrm{T}_{4}$ (i.e., $\mathrm{N}$ and $\mathrm{Cu}$ in marginal concentrations) when compared with the reported literatures $[27,29,32]$. Compared to the nutrient concentrations in the seedlings of $\mathrm{T}_{4}$, the increase in $\mathrm{N}$ and $\mathrm{P}$ concentrations in the seedlings of $\mathrm{T}_{3}$ was 1.7 and 3.5-fold in E. camaldulensis, 1.8- 
TABLE 1: Foliage nutrient concentration in 24-month-old planted seedlings of E. camaldulensis (Ec), A. nilotica (An), and Dalbergia sissoo (Ds) irrigated with varying levels of municipal effluent. Mean \pm SE of three replications in parentheses.

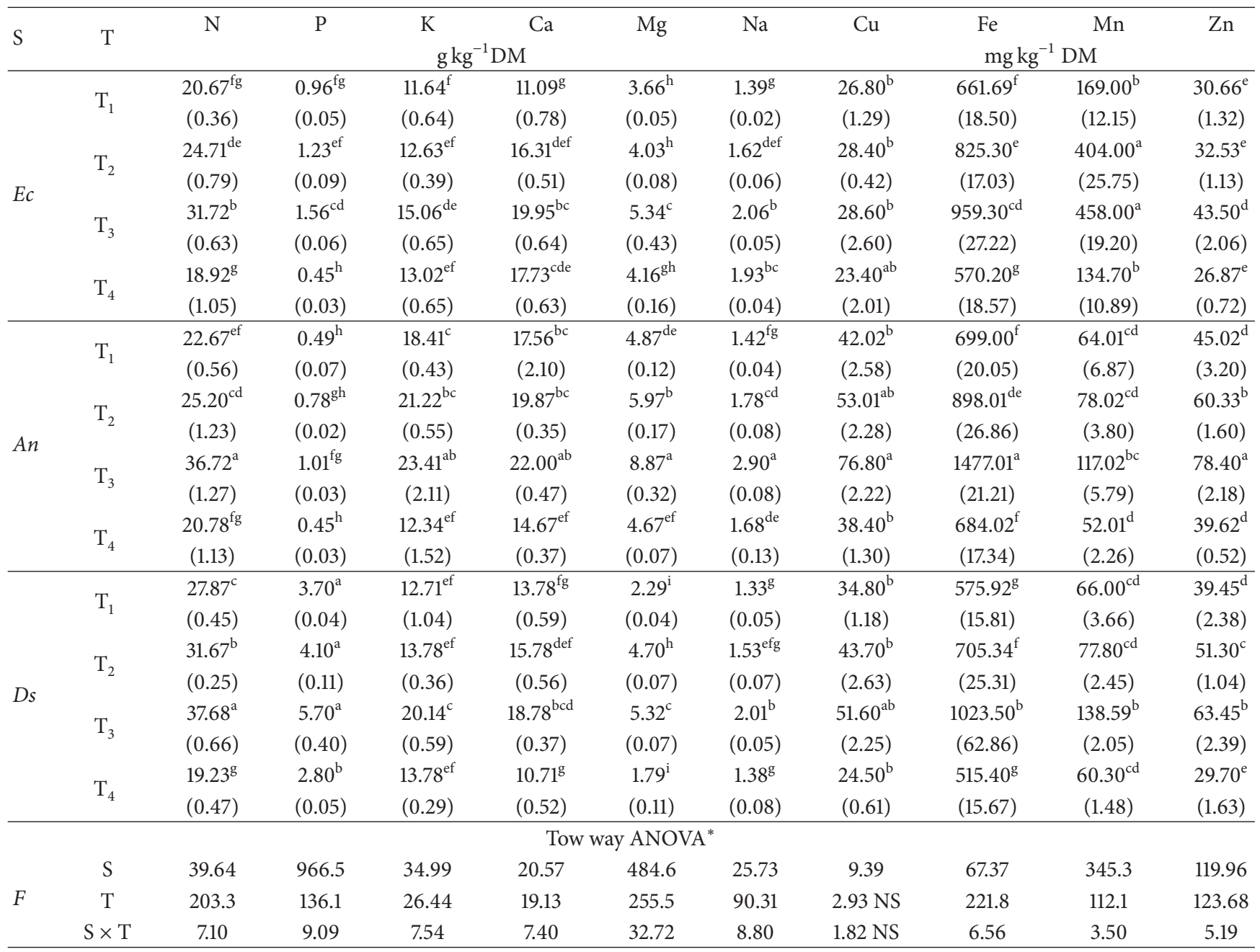

${ }^{*}$ ANOVA results are significant at $P<0.01$ except for $\mathrm{Cu}$, which was significant at $P<0.05$ for species but not significant (NS) at $P>0.05$ for treatment and species $(\mathrm{S}) \times$ treatment $(\mathrm{T})$ interaction.

The same letter in the same column means no significant difference $(P>0.05)$ between treatments (all three species).

and 2.2-fold in A. nilotica and 1.9- and 2.0-fold in D. sissoo. Concentrations of $\mathrm{K}, \mathrm{Ca}, \mathrm{Mg}$, and $\mathrm{Na}$ were 1.1- to 1.3 -fold in E. camaldulensis, 1.5- to 1.9-fold in A. nilotica and 1.5- to 3.0fold in D. sissoo. The increase in $\mathrm{Cu}, \mathrm{Fe}, \mathrm{Mn}$ and $\mathrm{Zn}$ was $1.2-$ to 3.4-fold, 2.0- to 2.3-fold and 2.0- to 2.3-fold in the respective species.

Differences in relative uptake of nutrients affected the treatments order $\left(\mathrm{T}_{1}\right.$ to $\left.\mathrm{T}_{4}\right)$ with increasing nutrients concentration ratios (Figure 2). The ratios of $\mathrm{K}: \mathrm{N}, \mathrm{Mg}: \mathrm{Na}, \mathrm{Zn}: \mathrm{Mn}$, and $\mathrm{Mg}$ : Mn differed $(P<0.01)$ due to both tree species and treatments. But significant variation $(P<0.05)$ in $\mathrm{Fe}: \mathrm{Mn}$ ratio was observed only between the species. Species $\times$ treatment interactions were also significant $(P<0.01)$. Among the treatments, the highest $\mathrm{K}: \mathrm{N}, \mathrm{K}: \mathrm{Mg}$ and $\mathrm{Ca}$, and $\mathrm{Fe}: \mathrm{Mn}$ ratios were in $\mathrm{T}_{4}$, and $\mathrm{Mg}: \mathrm{Na}, \mathrm{Zn}: \mathrm{Mn}$ and $\mathrm{Mg}: \mathrm{Mn}$ were in $\mathrm{T}_{2}$ treatments (Figure 2). The lowest ratios of $\mathrm{K}: \mathrm{N}$, Fe: $\mathrm{Mn}$, and $\mathrm{Zn}$ : $\mathrm{Mn}$ were in the seedlings of $\mathrm{T}_{3}, \mathrm{Mg}: \mathrm{Na}$ in $\mathrm{T}_{4}, \mathrm{~K}: \mathrm{Ca}$, and $\mathrm{Mg}$ in $\mathrm{T}_{2}$, and $\mathrm{Zn}: \mathrm{Mn}$ in $\mathrm{T}_{3}$ treatments.
Among the species, ratios of $\mathrm{K}: \mathrm{N}, \mathrm{K}: \mathrm{Ca}$ and $\mathrm{Mg}, \mathrm{Mg}: \mathrm{Na}$, $\mathrm{Fe}: \mathrm{Mn}, \mathrm{Mg}: \mathrm{Mn}$, and $\mathrm{Zn}: \mathrm{Mn}$ ranged from 0.4 to $0.9,0.6$ to $1.1,1.3$ to $4.5,2.1$ to $13.2,10.1$ to 102.7 , and 0.1 to 0.8 (Figure 2), respectively.

3.3. Leaf Water Relations. Leaf water potential $\left(\Psi_{l}\right)$ was the highest $(P<0.01)$ in the seedlings of $\mathrm{T}_{3}$ across species (Table 2). The highest $\Psi_{l}$ was in E. camaldulensis, but it did not differ with $D$. sissoo for $\Psi_{l}(P>0.05$, DMRT) across the treatments. The lowest $\Psi_{l}$ was in A. nilotica. Dalbergia sissoo indicated the highest $\Psi_{1}$ in $\mathrm{T}_{2}$, whereas $E$. camaldulensis showed greater $\Psi_{l}$ in $\mathrm{T}_{3}$ and $\mathrm{T}_{4}$ treatments (DMRT). The $\Psi_{l}$ was the highest $(P<0.01)$ in January (December in $E$. camaldulensis) that decreased gradually to the lowest value in May and then rose in July-August (Table 3). The lowest $\Psi_{l}$ was recorded for $A$. nilotica seedlings in most of the months. 

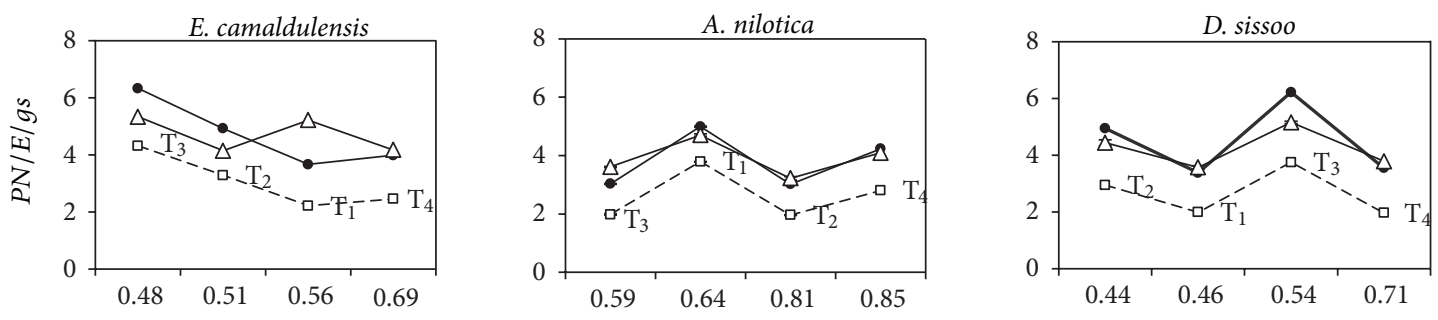

(a)
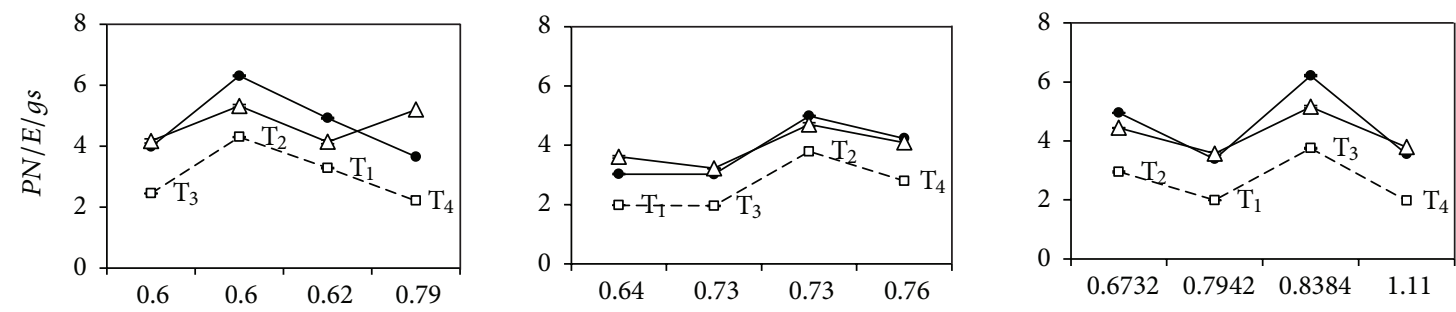

(b)
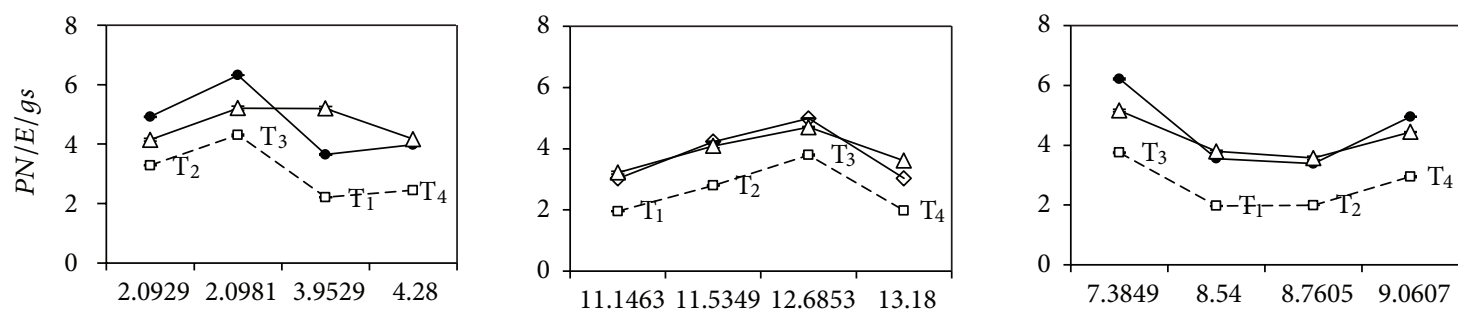

(c)
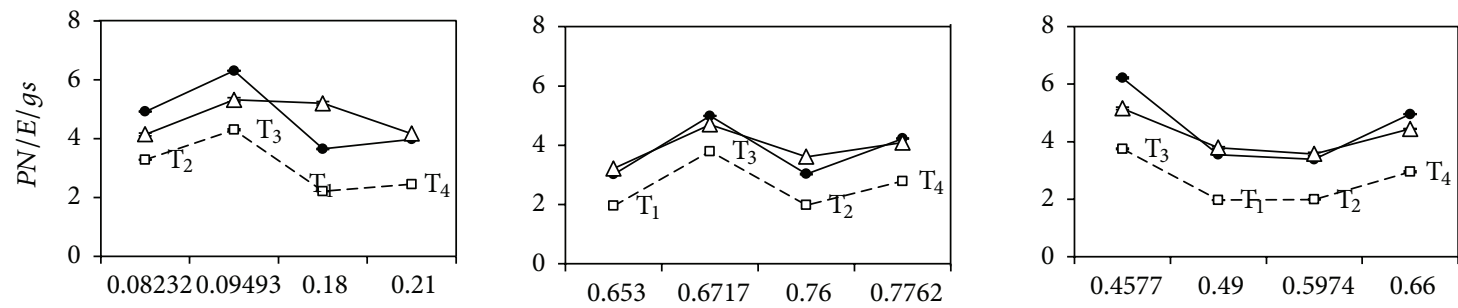

(d)
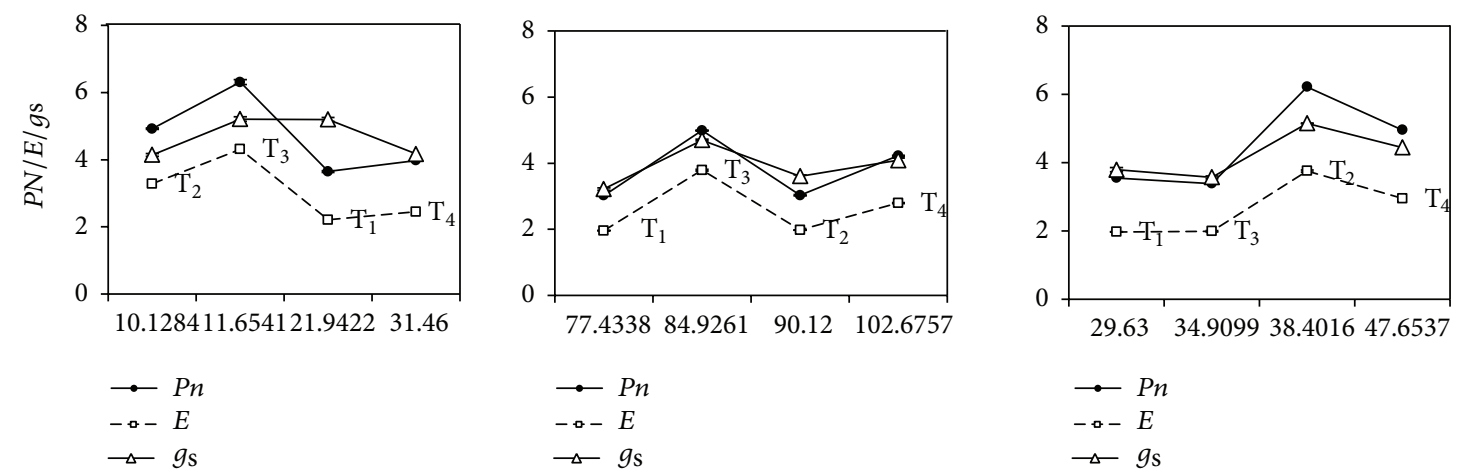

(e)

FIGURE 2: Ratios of mineral elements concentrations and their relationship with $P_{N}, E$, and $g_{\mathrm{S}}\left(\times 10^{-2}\right)$ influenced by tree species and level of municipal effluent application. Error bars are $\pm \mathrm{SE}$ of three replicates. $\mathrm{T}_{1}, \mathrm{~T}_{2}$, and $\mathrm{T}_{3}$ are municipal effluent irrigation levels of $1 / 2 \mathrm{PET}, 1 \mathrm{PET}$, and 2 PET, respectively. 
TABLE 2: Average values of physiological variables. Values are mean of 12 data (across treatments) for species and 9 data (across species) for treatments.

\begin{tabular}{|c|c|c|c|c|c|}
\hline \multirow{2}{*}{ Species/treatment } & \multicolumn{5}{|c|}{ Physiological variables } \\
\hline & LWP & $P_{N}$ & E & gs & WUE \\
\hline \multicolumn{6}{|c|}{ Average values across municipal effluent treatments for species } \\
\hline E. camaldulensis & $-2.01^{\mathrm{a}}$ & $4.72^{\mathrm{a}}$ & $3.06^{\mathrm{a}}$ & $42.96^{\mathrm{a}}$ & $1.56^{\mathrm{b}}$ \\
\hline A. nilotica & $-2.20^{\mathrm{b}}$ & $3.82^{\mathrm{c}}$ & $2.63^{\mathrm{c}}$ & $39.04^{\mathrm{b}}$ & $1.44^{\mathrm{c}}$ \\
\hline D. sissoo & $-1.99^{\mathrm{a}}$ & $4.53^{\mathrm{b}}$ & $2.67^{\mathrm{b}}$ & $42.41^{\mathrm{a}}$ & $1.66^{\mathrm{a}}$ \\
\hline \multicolumn{6}{|c|}{ Average values across tree species for municipal effluent treatment } \\
\hline $\mathrm{T}_{1}$ & $-2.28^{\mathrm{d}}$ & $3.35^{\mathrm{d}}$ & $2.05^{\mathrm{d}}$ & $34.45^{\mathrm{d}}$ & $1.57^{\mathrm{b}}$ \\
\hline $\mathrm{T}_{2}$ & $-2.01^{\mathrm{b}}$ & $4.70^{\mathrm{b}}$ & $3.01^{\mathrm{b}}$ & $42.25^{\mathrm{b}}$ & $1.55^{\mathrm{b}}$ \\
\hline $\mathrm{T}_{3}$ & $-1.81^{\mathrm{a}}$ & $5.84^{\mathrm{a}}$ & $3.95^{\mathrm{a}}$ & $50.63^{\mathrm{a}}$ & $1.48^{\mathrm{c}}$ \\
\hline $\mathrm{T}_{4}$ & $-2.15^{\mathrm{c}}$ & $3.52^{\mathrm{c}}$ & $2.13^{\mathrm{c}}$ & $38.56^{\mathrm{c}}$ & $1.62^{\mathrm{a}}$ \\
\hline \multicolumn{6}{|c|}{$F$ with significant level of two-way ANOVA } \\
\hline Species & $147.99^{* *}$ & $1683.38^{* *}$ & $709.21^{* *}$ & $61.38^{* *}$ & $336.17^{* *}$ \\
\hline Treatment & $335.54^{* *}$ & $7552.44^{* *}$ & $7335.46^{* *}$ & $483.82^{* *}$ & $61.14^{* *}$ \\
\hline Species $\times$ treatment & $19.81^{* *}$ & $86.79^{* *}$ & $22.29^{* *}$ & $9.16^{* *}$ & $25.38^{* *}$ \\
\hline
\end{tabular}

LWP: leaf water potential (MPa, Mega Pascal); $P_{N}$ : rate of photosynthesis $P_{N}$ : $\left(\mu \mathrm{mol} \mathrm{CO}_{2} \mathrm{~m}^{-2} \mathrm{~s}^{-1}\right) ; E$ : rate of transpiration $\left(\mathrm{mmol} \mathrm{m}^{-2} \mathrm{~s}^{-1}\right) ; g \mathrm{~g}:$ stomatal conductance $\left(\times 10^{-3} \mathrm{~mol} \mathrm{~m}^{-2} \mathrm{~s}^{-1}\right)$, and WUE: instantaneous water use efficiency $\left(P_{N} / E\right) . \mathrm{T}_{1}, \mathrm{~T}_{2}, \mathrm{~T}_{3}$, and $\mathrm{T}_{4}$ are irrigation of seedlings with municipal effluent at $1 / 2$ PET, 1 PET, 2 PET, and canal water at 1 PET, respectively. ${ }^{* *}$ Significant at $P<0.01$. The same letter in the same column means no significant difference $(P>0.05)$ between treatments/species.

The $\Psi_{l}$ was the highest for D. sissoo from April to August and that of A. nilotica from September to October.

3.4. Stomatal Conductance. Stomatal conductance $\left(g_{\mathrm{S}}\right)$ across the species increased $(P<0.01)$ in order $\mathrm{T}_{1}<\mathrm{T}_{4}<$ $\mathrm{T}_{2}<\mathrm{T}_{3}$ (Table 2). Considering species, $g_{\mathrm{S}}$ was highest $(P<0.01)$ in E. camaldulensis and lowest in A. nilotica. However, DMRT showed non-significant difference in $g_{\mathrm{S}}$ between E. camaldulensis and D. sissoo. D. sissoo indicated highest $(P<0.05) g_{\mathrm{S}}$ during April to August $\left(66.59 \pm 2.44 \times 10^{-3} \mathrm{~mol} \mathrm{~m}^{-2} \mathrm{~s}^{-1}\right) 2000$ (August 2000 in all treatments) and in E. amaldulensis in rest of the observations. From the lowest value in December/January, $g_{\mathrm{S}}$ increased by 1.8-fold in $\mathrm{T}_{1}, 1.7$-fold in $\mathrm{T}_{2}$ and $\mathrm{T}_{3}$ and 1.6-fold in the seedlings of $\mathrm{T}_{4}$ with wide temporal variation (Figure 3 , left panels).

3.5. Transpiration Rate. Rate of transpiration $(E)$ varied $(P<$ $0.01)$ within months, species and treatments. Across the species, $E$ was the lowest in the seedlings of $\mathrm{T}_{1}$. Average $E$ was $4 \%$ lesser in the seedlings of $\mathrm{T}_{1}$, but it increased by $46 \%$ and $85 \%$ in the seedlings of $\mathrm{T}_{2}$ and $\mathrm{T}_{3}$ treatment, respectively, as compared to $E$ value in $\mathrm{T}_{4}$ treatment (Table 2). Average across treatments, $E$ was the highest $(P<0.01)$ in $E$. camaldulensis and the lowest in A. nilotica seedlings. E. camaldulensis indicated the highest values (maximum of $7.80 \pm 0.26 \mathrm{mmol}$ $\mathrm{m}^{-2} \mathrm{~s}^{-1}$ in August 2000) of $E$ during January to April and July to September. A. nilotica indicated the highest $(2.97 \pm$ $0.04 \mathrm{mmol} \mathrm{m}^{-2} \mathrm{~s}^{-1}$ in December 1999) $E$ during December to February, whereas D. sissoo indicated the highest $(4.97 \pm$ $0.10 \mathrm{mmol} \mathrm{m}^{-2} \mathrm{~s}^{-1}$ in June 2000) $E$ in May and June. Rate of transpiration was the lowest in December/January (Figure 3(b)). It increased in March and April and decreased again in May before approaching the highest value in August.
$E$ ranged from 0.87 to $3.96 \mathrm{mmol} \mathrm{m}^{-2} \mathrm{~s}^{-1}$ in $\mathrm{T}_{1}, 1.40$ to $5.60 \mathrm{mmol} \mathrm{m}^{-2} \mathrm{~s}^{-1}$ in $\mathrm{T}_{2}, 1.96$ to $7.8 \mathrm{mmol} \mathrm{m}^{-2} \mathrm{~s}^{-1}$ in $\mathrm{T}_{3}$, and 1.0 to $3.99 \mathrm{mmol} \mathrm{m}^{-2} \mathrm{~s}^{-1}$ in $\mathrm{T}_{4}$ treatment, where the highest values were in $E$. camaldulensis seedlings. Species $\times$ treatment interaction was also significant $(P<0.05)$.

3.6. Net Photosynthesis Rate. Repeated measure ANOVA indicated variations $(P<0.01)$ in net photosynthesis rate $\left(P_{N}\right)$ due to species, treatments, and months. Average $P_{N}$ increased with quantity of applied effluent and seedlings of $\mathrm{T}_{3}$ treatments indicated the highest $P_{N}$ in all species. The lowest $P_{N}$ was in the seedlings of $\mathrm{T}_{1}$ in most of the months and in $\mathrm{T}_{4}$ in April, May, August, and September. When compared with the seedlings of $\mathrm{T}_{4}, P_{N}$ increased by $34 \%$ and $66 \%$ in the seedlings of $\mathrm{T}_{2}$ and $\mathrm{T}_{3}$, respectively, whereas it was $5 \%$ less in $T_{1}$ treatment. Across the treatments, the highest and lowest values of $P_{N}$ were in E. camaludensisis and A. nilotica, respectively (Table 2 ). However, tempral variation indicated the highest $P_{N}$ in E. camaldulensis in most of the observations (maximum of $13.56 \pm 0.34 \mu \mathrm{mol} \mathrm{CO} \mathrm{m}^{-2} \mathrm{~s}^{-1}$ in August 2000, mean $\pm 1 \mathrm{SE})$, in D. sissoo in April, May, June, and July (6.35 \pm $0.36 \mu \mathrm{mol} \mathrm{CO} \mathrm{m}^{-2} \mathrm{~s}^{-1}$ ) and in A. nilotica in October 2000 $\left(5.2 \pm 0.05 \mu \mathrm{mol} \mathrm{CO} 2 \mathrm{~m}^{-2} \mathrm{~s}^{-1}\right.$ in $\left.\mathrm{T}_{3}\right)$. There was a significant $(P<0.01)$ seasonal pattern in $P_{N}$ with two maxima, that is, August and again in March/April (Figure 4(a)). $P_{N}$ value in August was 6.2- to 7.1-fold in $\mathrm{T}_{1}, 4.0$ - to 5.2-fold in $\mathrm{T}_{2}, 3.9$ to 4.5-fold in $\mathrm{T}_{3}$, and 4.0- to 5.7-fold in the seedlings of $\mathrm{T}_{4}$ as compared to the respective $P_{N}$ value in December/January. Seedlings of $D$. sissoo showed the highest seasonal variations in $P_{N}$ among the species.

3.7. Instantaneous Water Use Efficiency. Repeated measure ANOVA showed significant $(P<0.01)$ variation in water use efficiency (WUE), that is, $P_{N} / E\left(\mu \mathrm{mol} \mathrm{CO} \mathrm{mmol}^{-1} \mathrm{H}_{2} \mathrm{O}\right)$ 
TABLE 3: Leaf water potential (-MPa) of trees seedlings of E. camaldulensis (Ec), A. nilotica (An), and Dalbergia sissoo (Ds) irrigated with varying levels of municipal effluent. Mean \pm SE of three replications in parentheses.

\begin{tabular}{|c|c|c|c|c|c|c|c|c|c|c|c|c|c|}
\hline$S$ & $\mathrm{~T}$ & December & January & February & March & April & May & June & July & August & September & October & November \\
\hline \multirow{8}{*}{$E c$} & \multirow{2}{*}{$\mathrm{T}_{1}$} & 1.65 & 1.71 & 1.92 & 2.09 & 2.65 & 3.00 & 2.76 & 2.76 & 2.38 & 2.48 & 2.65 & 2.10 \\
\hline & & $(0.04)$ & $(0.03)$ & $(0.04)$ & $(0.05)$ & $(0.05)$ & $(0.02)$ & $(0.04)$ & $(0.05)$ & $(0.09)$ & $(0.06)$ & $(0.06)$ & $(0.04)$ \\
\hline & \multirow{2}{*}{$\mathrm{T}_{2}$} & 1.38 & 1.43 & 1.60 & 1.93 & 2.15 & 2.52 & 2.11 & 1.97 & 2.29 & 2.35 & 2.35 & 1.48 \\
\hline & & $(0.06)$ & $(0.02)$ & $(0.05)$ & $(0.03)$ & $(0.04)$ & $(0.04)$ & $(0.04)$ & $(0.05)$ & $(0.05)$ & $(0.04)$ & $(0.03)$ & $(0.03)$ \\
\hline & \multirow{2}{*}{$\mathrm{T}_{3}$} & 1.00 & 1.14 & 1.43 & 1.72 & 1.81 & 2.20 & 2.05 & 1.65 & 1.50 & 1.84 & 2.07 & 1.33 \\
\hline & & $(0.04)$ & $(0.05)$ & $(0.02)$ & $(0.02)$ & $(0.04)$ & $(0.05)$ & $(0.08)$ & $(0.04)$ & $(0.05)$ & $(0.04)$ & $(0.06)$ & $(0.02)$ \\
\hline & \multirow{2}{*}{$\mathrm{T}_{4}$} & 1.57 & 1.63 & 1.83 & 2.01 & 2.04 & 2.81 & 2.19 & 2.19 & 2.32 & 2.42 & 2.47 & 1.62 \\
\hline & & $(0.05)$ & $(0.03)$ & $(0.04)$ & $(0.04)$ & $(0.05)$ & $(0.04)$ & $(0.07)$ & $(0.06)$ & $(0.07)$ & $(0.04)$ & $(0.06)$ & $(0.03)$ \\
\hline \multirow{8}{*}{$A n$} & \multirow{2}{*}{$\mathrm{T}_{1}$} & 1.95 & 1.92 & 2.24 & 2.75 & 2.80 & 3.19 & 2.87 & 2.47 & 2.10 & 2.14 & 2.01 & 2.01 \\
\hline & & $(0.06)$ & $(0.03)$ & $(0.04)$ & $(0.14)$ & $(0.04)$ & $(0.06)$ & $(0.06)$ & $(0.05)$ & $(0.06)$ & $(0.06)$ & $(0.06)$ & $(0.07)$ \\
\hline & \multirow{2}{*}{$\mathrm{T}_{2}$} & 1.85 & 1.81 & 1.98 & 2.23 & 2.37 & 2.82 & 2.51 & 2.01 & 1.93 & 1.98 & 1.90 & 1.87 \\
\hline & & $(0.02)$ & $(0.02)$ & $(0.03)$ & $(0.04)$ & $(0.05)$ & $(0.10)$ & $(0.03)$ & $(0.05)$ & $(0.04)$ & $(0.06)$ & $(0.04)$ & $(0.04)$ \\
\hline & \multirow{2}{*}{$\mathrm{T}_{3}$} & 1.80 & 1.73 & 1.89 & 2.03 & 2.15 & 2.63 & 2.30 & 1.93 & 1.82 & 1.92 & 1.89 & 1.82 \\
\hline & & $(0.03)$ & $(0.02)$ & $(0.05)$ & $(0.09)$ & $(0.02)$ & $(0.08)$ & $(0.04)$ & $(0.07)$ & $(0.03)$ & $(0.04)$ & $(0.04)$ & $(0.04)$ \\
\hline & \multirow{2}{*}{$\mathrm{T}_{4}$} & 1.93 & 1.91 & 2.13 & 2.55 & 2.61 & 2.93 & 2.83 & 2.32 & 2.02 & 2.10 & 1.99 & 1.96 \\
\hline & & $(0.02)$ & $(0.02)$ & $(0.04)$ & $(0.05)$ & $(0.03)$ & (90.1) & $(0.02)$ & $(0.02)$ & $(0.07)$ & $(0.05)$ & $(0.03)$ & $(0.05)$ \\
\hline \multirow{8}{*}{ Ds } & \multirow{2}{*}{$\mathrm{T}_{1}$} & 1.96 & 1.87 & 1.95 & 2.13 & 2.23 & 2.39 & 2.31 & 2.09 & 2.01 & 2.29 & 2.28 & 2.09 \\
\hline & & $(0.02)$ & $(0.05)$ & $(0.04)$ & $(0.03)$ & $(0.04)$ & $(0.04)$ & $(0.02)$ & $(0.03)$ & $(0.03)$ & $(0.02)$ & $(0.02)$ & $(0.03)$ \\
\hline & \multirow{2}{*}{$\mathrm{T}_{2}$} & 1.79 & 1.57 & 1.73 & 1.89 & 2.07 & 2.27 & 2.18 & 1.92 & 1.90 & 2.20 & 2.07 & 1.87 \\
\hline & & $(0.03)$ & $(0.05)$ & $(0.03)$ & $(0.06)$ & $(0.05)$ & $(0.03)$ & $(0.01)$ & $(0.02)$ & $(0.02)$ & $(0.02)$ & $(0.03)$ & $(0.02)$ \\
\hline & \multirow{2}{*}{$\mathrm{T}_{3}$} & 1.63 & 1.40 & 1.62 & 1.77 & 1.89 & 2.22 & 2.01 & 1.85 & 1.73 & 1.89 & 1.82 & 1.71 \\
\hline & & $(0.05)$ & $(0.04)$ & $(0.02)$ & $(0.06)$ & $(0.04)$ & $(0.03)$ & $(0.06)$ & $(0.08)$ & $(0.02)$ & $(0.02)$ & $(0.04)$ & $(0.04)$ \\
\hline & \multirow{2}{*}{$\mathrm{T}_{4}$} & 1.91 & 1.82 & 1.84 & 2.07 & 2.21 & 2.26 & 2.22 & 1.97 & 1.98 & 2.19 & 2.17 & 2.01 \\
\hline & & $(0.04)$ & $(0.04)$ & $(0.04)$ & $(0.06)$ & $(0.03)$ & $(0.03)$ & $(0.03)$ & $(0.01)$ & $(0.02)$ & $(0.03)$ & $(0.04)$ & $(0.02)$ \\
\hline
\end{tabular}

Repeated Measure ANOVA*

Tests of within subjects effects

Tests of between subjects effects

\begin{tabular}{cccccccccc} 
& df & MSE & $F$ value & $P$ value & & df & MSE & $F$ value & $P$ value \\
\hline $\mathrm{M}$ & 11 & 2.507 & 435.84 & $<0.001$ & $\mathrm{~S}$ & 2 & 1.948 & 147.99 & $<0.001$ \\
$\mathrm{M} \times \mathrm{S}$ & 22 & 0.372 & 64.69 & $<0.001$ & $\mathrm{~T}$ & 3 & 4.417 & 335.54 & $<0.001$ \\
$\mathrm{M} \times \mathrm{T}$ & 33 & 0.031 & 5.32 & $<0.001$ & $\mathrm{~S} \times \mathrm{T}$ & 6 & 0.261 & 19.81 & $<0.001$ \\
$\mathrm{M} \times \mathrm{S} \times \mathrm{T}$ & 66 & 0.041 & 7.06 & $<0.001$ & & & & & \\
\hline
\end{tabular}

*ANOVA results are significant at $P<0.01$ except in February and March when it was significant at $P<0.05$ for species $\times$ treatment interaction. M, month; $\mathrm{S}$, species and $\mathrm{T}$, treatments.

between the species, treatments, and months. WUE was the highest $(P<0.01)$ in $\mathrm{T}_{4}$ and the lowest in $\mathrm{T}_{3}$ seedlings across the species. However, WUE did not differ significantly between the seedlings of $\mathrm{T}_{1}$ and $\mathrm{T}_{2}$ treatments (DMRT). Among the tree species, the highest $(P<0.05)$ WUE was in the seedlings of $D$. sissoo and the lowest in A. nilotica (Figure 4(b)). When compared with the lowest WUE (observed either in winter or in summer), a 2.1- to 2.6-fold greater WUE was observed in the seedlings of $\mathrm{T}_{1}$, whereas the increase was 1.9- to 2.4-fold in $\mathrm{T}_{2}, 1.7$ - to 2.6-fold in $\mathrm{T}_{3}$, and 1.9- to 2.2-fold in $\mathrm{T}_{4}$ treatments. Relative increase in WUE was highest in D. sissoo (Figure 4(a)).

3.8. Correlations and Regressions. Nutrient concentrations in foliage of the seedlings were positively correlated $(r=0.453$ to $0.841, P<0.05, n=27$ ) to total applied municipal effluent (except for $\mathrm{P}$ and $\mathrm{Mn}$ ). Fe, $\mathrm{P}, \mathrm{Na}, \mathrm{Mn}$ and $\mathrm{N}$ showed positive $(r=0.426$ to $0.716, P<0.05)$ and $\mathrm{K}: \mathrm{N}$ ratio showed negative $(r=-0.496, P<0.05)$ relationship with $\Psi_{l}$. Total quantity of applied effluent showed positive relationship with average $\Psi_{l}$, $P_{N}, E$, and $g_{S}(r=0.429$ to $0.939, P<0.05)$. Concentrations of foliage $\mathrm{N}, \mathrm{P}, \mathrm{Fe}, \mathrm{Mn}$, and $\mathrm{Zn}(r=0.385$ to $0.728, P<$ $0.05)$ were positively correlated with average $P_{N}$. Average $E$ showed positive correlations $(r=0.451$ to $0.715, P<$ 0.05 ) with $\mathrm{N}, \mathrm{Ca}, \mathrm{Mg}, \mathrm{Fe}, \mathrm{Mn}$, and $\mathrm{Zn}$ concentrations, but we did not find relations $(P>0.05)$ of these nutrients with stomatal conductance. Ratios of mineral elements did not show significant relationship with physiological variables except for negative correlation of $P_{N}(r=-0.412, P<0.05)$ with $\mathrm{K}: \mathrm{N}$; and WUE with $\mathrm{K}: \mathrm{N}(r=-0.465, P<0.05)$, $\mathrm{Mg}: \mathrm{Na}(r=-0.554, P<0.01)$, and $\mathrm{Mg}: \mathrm{Mn}(r=-0.488$, $P<0.01)$. WUE showed negative correlations $(r=-0.435$ to $-0.684, P<0.05)$ with foliage nutrients concentration in tree seedlings. 

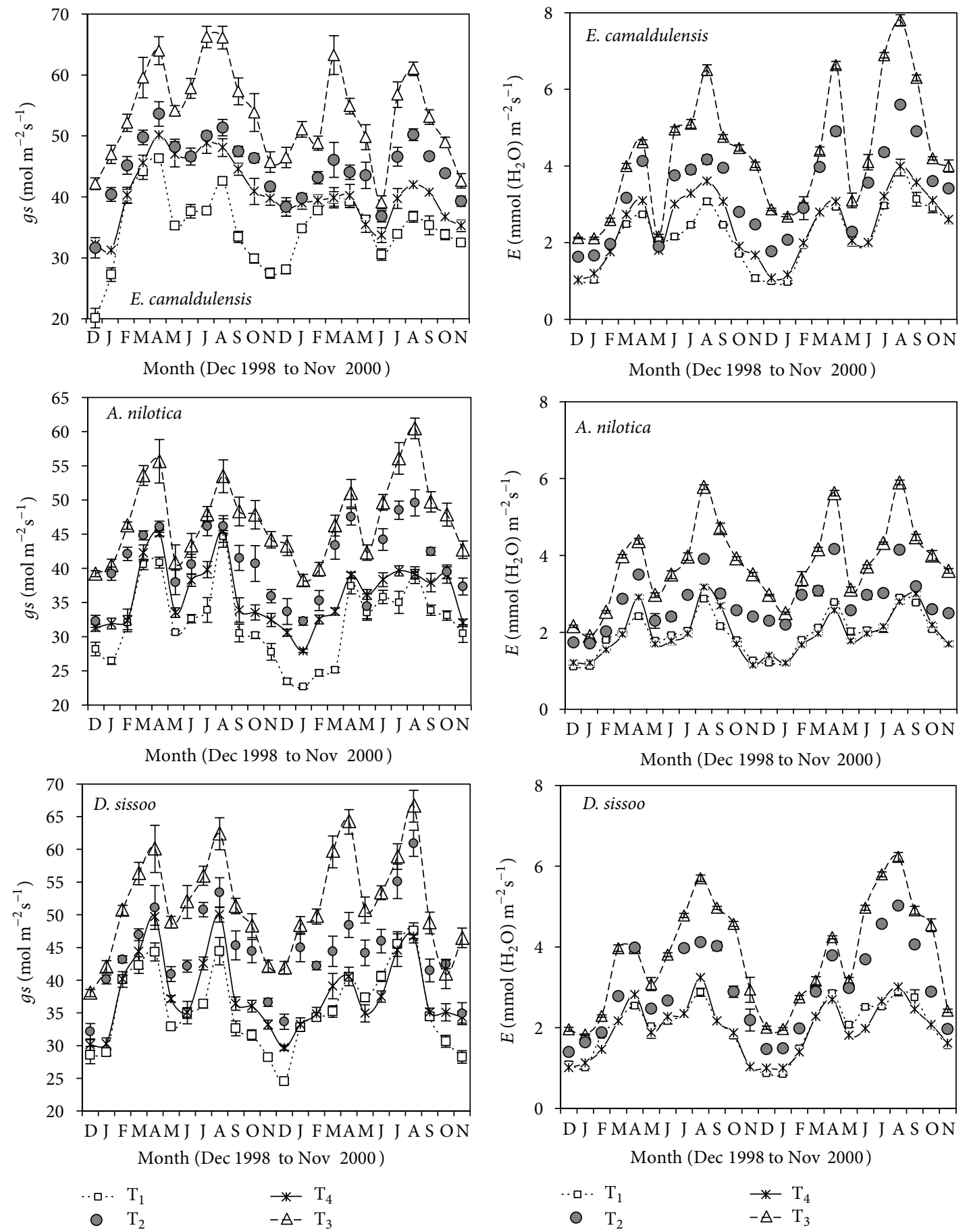

(a)

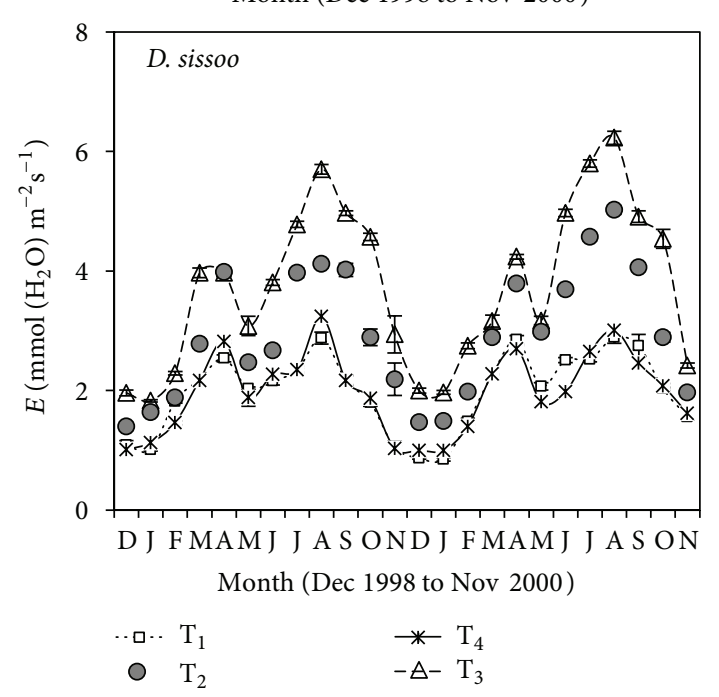

(b)

FIGURE 3: Monthly changes in stomatal conductance $\left(g_{\mathrm{S}} \times 10^{-3},(\mathrm{a})\right)$ and transpiration rate $(E,(\mathrm{~b}))$ of tree seedlings irrigated with canal water and varying levels of municipal effluent during 1998-99 and 1999-00. Error bars are $\pm S E . \mathrm{T}_{1}, \mathrm{~T}_{2}, \mathrm{~T}_{3}$, and $\mathrm{T}_{4}$ are irrigation of seedlings with municipal effluent at 1/2 PET, 1 PET, 2 PET, and canal water at $1 \mathrm{PET}$, respectively.

Regressions equations (irrespective of species and treatments) between physiological functions and foliage nutrients concentration showed nonlinear relationships $(P<$ $0.05)$. Nitrogen and $P$ concentrations showed linear relations to $P_{N}$ and WUE, respectively (Table 4). Net photosynthesis and transpiration rates showed linear relations with slope value of 1.266, 1.067, and 1.605 for E. camaldulensis, A. nilotica, and D. sissoo (Supplementary Figure 1) Both $P_{N}$ and $E$ increased $(P<0.05)$ with increase in nutrient concentrations except $\mathrm{Cu}$, which did not indicate any relation with $E$. WUE 

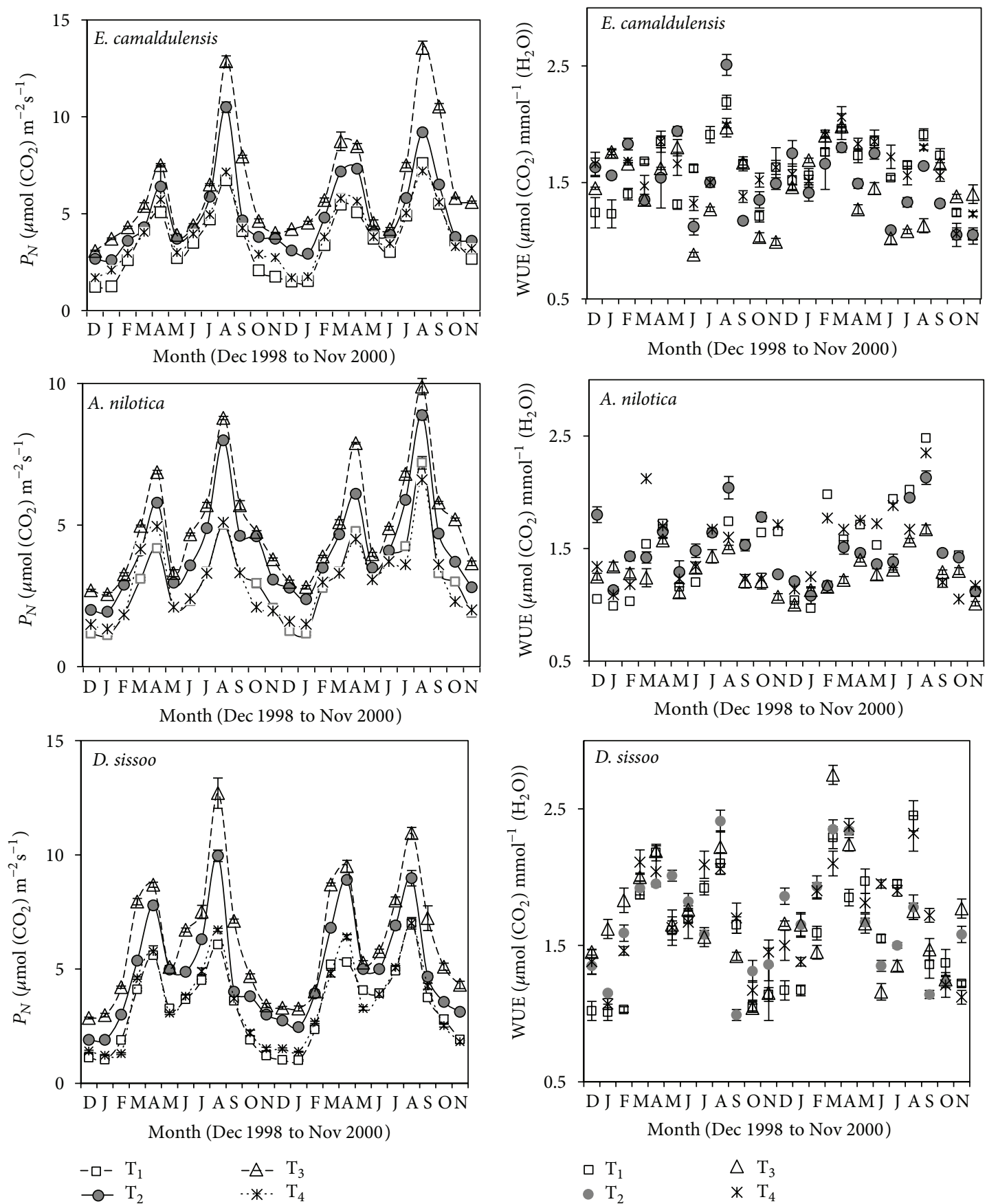

(a)

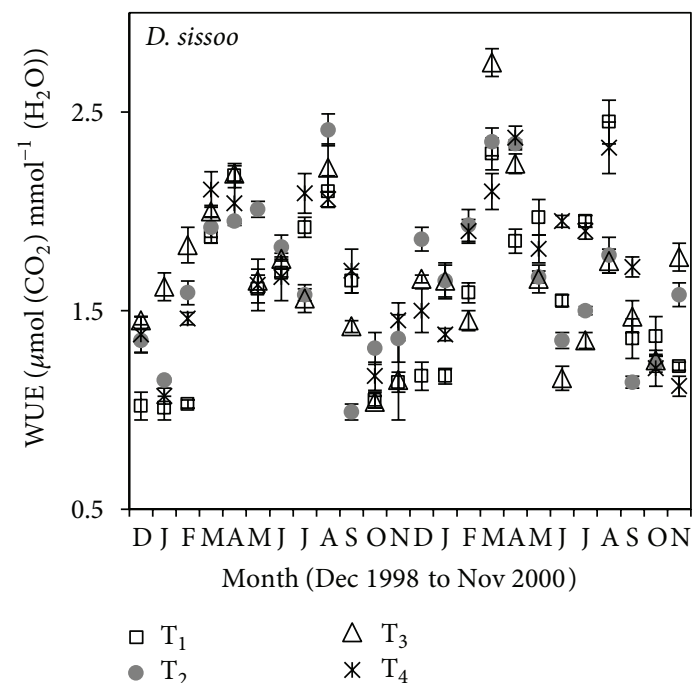

(b)

FIGURE 4: Monthly changes in net photosynthetic rate $\left(P_{N},(a)\right)$ and instantaneous water use efficiency (WUE, (b)) irrigated with canalwater and varying levels of municipal effluents during 1998-99 and 1999-00. Error bars are $\pm S E . T_{1}, T_{2}, T_{3}$, and $T_{4}$ are irrigation of seedlings with municipal effluent at 1/2 PET, 1 PET, 2 PET, and canal water at 1 PET, respectively.

was influenced by foliage biochemistry resulting in variations in $P_{N} / E$ ratio, which decreased with increase in nutrient concentration, but $\mathrm{P}$ concentration was positively related (Figure 5). WUE increased with increase in $\mathrm{Mg}: \mathrm{Na}, \mathrm{Fe}: \mathrm{Mn}$, $\mathrm{Zn}: \mathrm{Mn}$ and $\mathrm{Mg}: \mathrm{Mn}$ ratios but decreased when their ratio increased above $1.9,6.67,0.2$, and 34.1, respectively. Increase in $\mathrm{Ca}, \mathrm{Na}$, and $\mathrm{Fe}$ concentrations influenced $(P<0.05)$ $P_{N}$ positively but their respective concentration of greater than $22.26 \mathrm{~g} \mathrm{~kg}^{-1}, 2.76 \mathrm{~g} \mathrm{~kg}^{-1}$, and $1146 \mathrm{mg} \mathrm{kg}^{-1}$ reduced $P_{N}$ (Table 4, Figure 5). Likewise greater than $1.65 \mathrm{~g} \mathrm{~kg}^{-1}$, $21.09 \mathrm{~g} \mathrm{~kg}^{-1}$, and $2.76 \mathrm{~g} \mathrm{~kg}^{-1}$ concentrations of $\mathrm{P}, \mathrm{Ca}$, and $\mathrm{Na}$ respectively, reduced $E$. 
TABLE 4: Regression equations* between mineral element concentrations and net photosynthesis rate, transpiration rate, stomatal conductance, and instantaneous water use efficiency as the dependent variables and mineral concentrations as independent variables.

\begin{tabular}{|c|c|c|c|c|c|c|c|c|c|}
\hline Variable & Equation & $a_{0}$ & $b_{1}$ & $b_{2}$ & $b_{3}$ & $R^{2}$ & SE & $F$ value & $P$ value \\
\hline \multicolumn{10}{|c|}{ Rate of photosynthesis $\left(P_{N}\right)$} \\
\hline $\mathrm{N}$ & Logarithm & -8.62930 & 3.97209 & - & - & 0.5319 & 0.7837 & 28.40 & 0.000 \\
\hline $\mathrm{P}$ & Sigmoid & 1.69905 & -0.23188 & - & - & 0.3166 & 0.2094 & 11.58 & 0.002 \\
\hline $\mathrm{Ca}$ & Cubic & 12.29345 & -2.00749 & 0.14362 & -0.0031 & 0.3759 & 0.9434 & 4.62 & 0.011 \\
\hline $\mathrm{Mg}$ & Sigmoid & 1.75381 & -1.10272 & - & - & 0.1790 & 0.2295 & 5.45 & 0.027 \\
\hline $\mathrm{Na}$ & Quadratic & -8.92904 & 12.89990 & -2.77332 & - & 0.7060 & 0.6338 & 28.82 & 0.000 \\
\hline $\mathrm{Fe}$ & Quadratic & -5.02941 & 0.01869 & -0.00001 & - & 0.5924 & 0.7464 & 17.43 & 0.000 \\
\hline $\mathrm{Mn}$ & Inverse & 5.97239 & -1.44654 & - & - & 0.4325 & 0.8629 & 19.05 & 0.000 \\
\hline $\mathrm{Zn}$ & Power & 1.25817 & 0.33138 & - & - & 0.1712 & 0.2306 & 5.16 & 0.031 \\
\hline $\mathrm{K} / \mathrm{N}$ & Compound & 6.71215 & 0.50522 & - & - & 0.1710 & 0.2306 & 5.16 & 0.032 \\
\hline $\mathrm{Fe} / \mathrm{Mn}$ & Inverse & 4.07304 & 2.71389 & - & - & 0.1638 & 1.0474 & 4.90 & 0.036 \\
\hline \multicolumn{10}{|c|}{ Rate of transpiration $(E)$} \\
\hline $\mathrm{N}$ & Linear & 0.16705 & 0.09866 & - & - & 0.5111 & 0.5815 & 26.13 & 0.000 \\
\hline $\mathrm{P}$ & Cubic & 0.85675 & 3.25457 & -1.13713 & 0.1113 & 0.3623 & 0.6823 & 4.36 & 0.014 \\
\hline $\mathrm{K}$ & Sigmoid & 1.45824 & -6.13854 & - & - & 0.1242 & 0.2677 & 3.55 & 0.071 \\
\hline $\mathrm{Ca}$ & Cubic & 12.73548 & -2.24278 & 0.14900 & 0.002986 & 0.5185 & 0.6016 & 8.25 & 0.000 \\
\hline $\mathrm{Mg}$ & Sigmoid & 1.45201 & -1.17157 & - & - & 0.3397 & 0.2325 & 12.86 & 0.001 \\
\hline $\mathrm{Na}$ & Quadratic & -5.60495 & 7.83469 & -1.57456 & - & 0.7883 & 0.3901 & 44.80 & 0.000 \\
\hline $\mathrm{Fe}$ & Sigmoid & 1.96642 & -729.363 & - & - & 0.6725 & 0.1637 & 51.33 & 0.000 \\
\hline $\mathrm{Cu}$ & Cubic & 13.22883 & -0.68615 & 0.01381 & -0.000084 & 0.2865 & 0.7323 & 3.08 & 0.047 \\
\hline $\mathrm{Mn}$ & Inverse & 4.01221 & -108.593 & - & - & 0.4637 & 0.6090 & 21.61 & 0.000 \\
\hline $\mathrm{Zn}$ & Compound & 1.86315 & 1.00904 & - & - & 0.2454 & 0.2485 & 8.13 & 0.008 \\
\hline $\mathrm{Fe} / \mathrm{Mn}$ & Inverse & 2.58987 & 2.01328 & - & - & 0.1711 & 0.7571 & 5.16 & 0.032 \\
\hline $\mathrm{Zn} / \mathrm{Mn}$ & Inverse & 2.68570 & 0.07460 & - & - & 0.1564 & 0.7638 & 4.63 & 0.041 \\
\hline \multicolumn{10}{|c|}{ Stomatal conductance $(g s)$} \\
\hline $\mathrm{N}$ & Compound & 28.39680 & 1.01473 & - & - & 0.1622 & 0.2003 & 4.83 & 0.037 \\
\hline $\mathrm{Na}$ & Sigmoid & 4.24489 & -0.79956 & - & - & 0.2381 & 0.1910 & 7.81 & 0.009 \\
\hline $\mathrm{Fe}$ & Sigmoid & 4.08435 & -256.357 & - & - & 0.1420 & 0.2027 & 4.14 & 0.052 \\
\hline $\mathrm{Mn}$ & Sigmoid & 3.9789 & -22.8573 & - & - & 0.2967 & 0.1835 & 10.55 & 0.003 \\
\hline \multicolumn{10}{|c|}{ Instantaneous water use efficiency (WUE) } \\
\hline $\mathrm{P}$ & Linear & 1.43590 & 0.04460 & - & - & 0.4673 & 0.0869 & 21.93 & 0.000 \\
\hline K & Compound & 1.81403 & 0.98970 & - & - & 0.3293 & 0.0655 & 12.27 & 0.001 \\
\hline $\mathrm{Ca}$ & Compound & 1.8993 & 0.98773 & - & - & 0.3669 & 0.0636 & 14.49 & 0.000 \\
\hline $\mathrm{Mg}$ & Compound & 1.76437 & 0.97289 & - & - & 0.6349 & 0.0483 & 43.48 & 0.000 \\
\hline $\mathrm{Na}$ & Compound & 1.86695 & 0.89376 & - & - & 0.4765 & 0.0579 & 22.75 & 0.000 \\
\hline $\mathrm{Fe}$ & Compound & 1.83373 & 0.99979 & - & - & 0.5011 & 0.0565 & 25.10 & 0.000 \\
\hline $\mathrm{Cu}$ & Compound & 1.71655 & 0.99728 & - & - & 0.3036 & 0.0667 & 10.90 & 0.002 \\
\hline $\mathrm{Zn}$ & Compound & 1.71518 & 0.99764 & - & - & 0.2151 & 0.0708 & 6.85 & 0.014 \\
\hline $\mathrm{K} / \mathrm{N}$ & Inverse & 1.28251 & 0.13853 & - & - & 0.2370 & 0.1039 & 7.76 & 0.010 \\
\hline $\mathrm{Mg} / \mathrm{Na}$ & Cubic & 0.41192 & 1.46011 & -0.54740 & 0.0606 & 0.4673 & 0.0905 & 6.72 & 0.002 \\
\hline $\mathrm{Fe} / \mathrm{Mn}$ & Quadratic & 1.34984 & 0.09269 & -0.00715 & - & 0.7007 & 0.0665 & 28.10 & 0.000 \\
\hline $\mathrm{Zn} / \mathrm{Mn}$ & Cubic & 1.30110 & 2.78703 & -6.07910 & 3.5243 & 0.2924 & 0.1044 & 3.17 & 0.043 \\
\hline $\mathrm{Mg} / \mathrm{Mn}$ & Cubic & 1.30661 & 0.02323 & -0.00047 & 0.000003 & 0.6924 & 0.0688 & 17.26 & 0.000 \\
\hline
\end{tabular}

${ }^{*}$ Nonsignificant $(P>0.05)$ relations have not been shown. $a_{0}, b_{1}, b_{2}$, and $b_{3}$ are regression constants. $R^{2}$ : coefficient of determination and SE: standard error.

\section{Discussion}

4.1. Foliage Nutrients and Water Relations. The results of this study showed beneficial effects of municipal effluent on the physiological functions of E. camaldulensis, A. nilotica, and $D$. sissoo seedlings. Because of essential in nature, these nutrients were transported to and accumulated $(P<0.01)$ in foliar parts with increased effluent quantity from $T_{1}$ to $T_{3}$. Greater concentrations of the most of the nutrients in the seedlings in $\mathrm{T}_{2}$ and $\mathrm{N}, \mathrm{P}, \mathrm{Fe}$, and $\mathrm{Zn}$ in $\mathrm{T}_{1}$ as compared to the seedlings in 

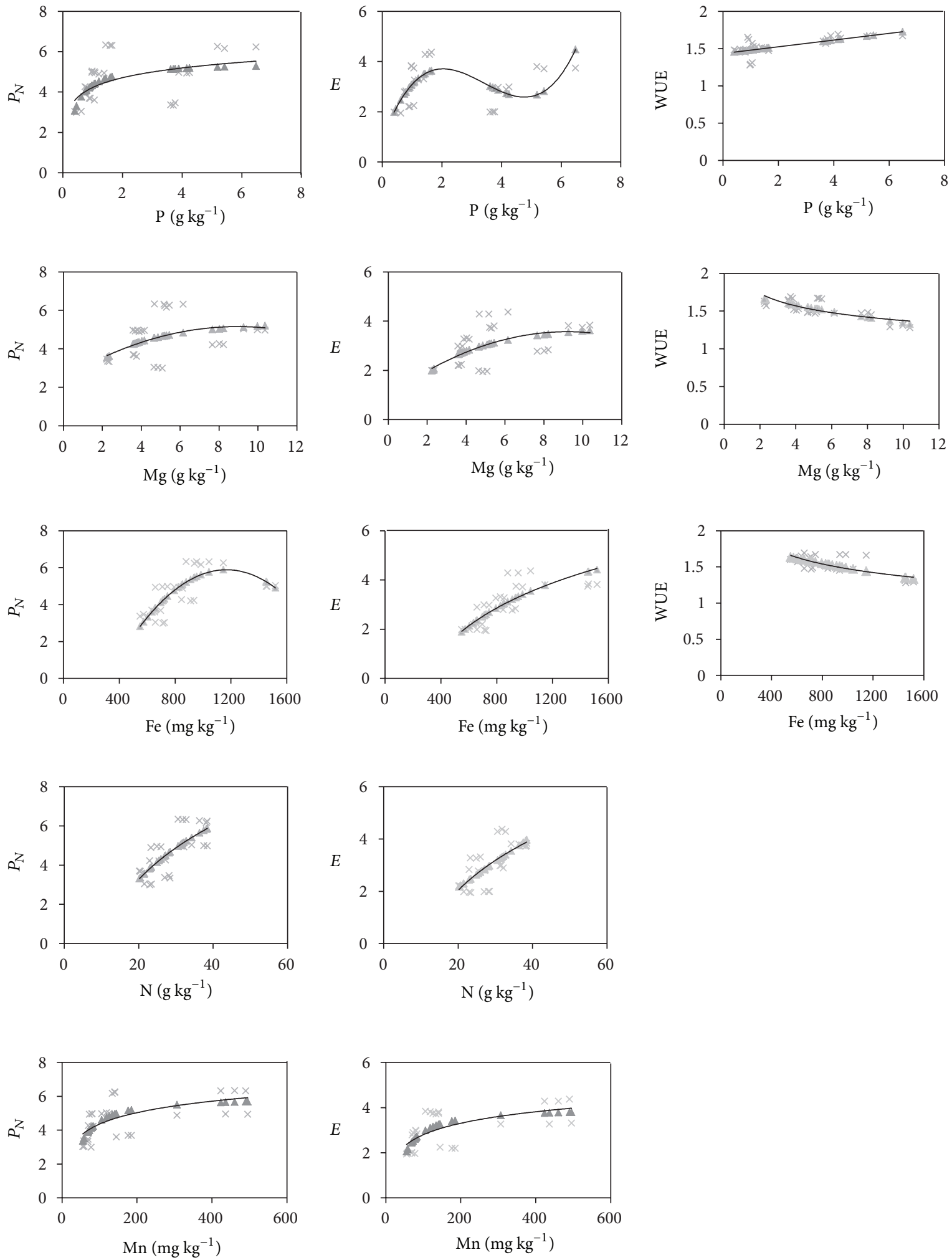

FIGURE 5: Relationship of mineral concentrations with average rate of net photosynthesis $\left(P_{N}, \mu \mathrm{mol} \mathrm{CO}_{2} \mathrm{~m}^{-2} \mathrm{~s}^{-1}\right)$, transpiration $\left(E\right.$, mmol m${ }^{-2}$ $\left.\mathrm{s}^{-1}\right)$, and instantaneous water use efficiency in tree seedlings irrigated with varying levels of municipal effluent. The observed and estimated trend in values are shown by cross $(x)$ and solid line, respectively. 
$\mathrm{T}_{4}$ treatment (despite same quantity of water in $\mathrm{T}_{2}$ and half quantity of water in $\mathrm{T}_{1}$ treatment) were due to the nutrients applied through municipal effluent. Relatively greater accumulation of $\mathrm{Mn}, \mathrm{Fe}, \mathrm{Cu}$, and $\mathrm{Zn}$ (10\% to 2.9-fold in effluent irrigated than in $\left.\mathrm{T}_{4}\right)$ as compared to $\mathrm{N}, \mathrm{K}, \mathrm{Ca}$, and $\mathrm{Mg}(2 \%$ to $93 \%$ ) showed an increase in absorption and mobility of the former elements under increased level of effluent irrigation [26]. However, absence of any toxic effect on the tree seedlings showed that the nutrient concentrations were adequate [2729] or lesser than the critical concentrations observed in other studies [30, 31]. The differential accumulation of nutrients varied with species characteristics influencing $\Psi_{l}$ and ratios of the nutrient concentrations in plant system. The highest concentration of $\mathrm{Ca}, \mathrm{Mg}, \mathrm{K}, \mathrm{Na}, \mathrm{Cu}, \mathrm{Fe}$, and $\mathrm{Zn}$ in A. nilotica seedlings particularly basic cations (Table 1) was related to reduced $\Psi_{l}$ and physiological functions by increasing solute concentration. Lesser concentrations of these nutrients in E. camaldulnsis and D. sissoo were due to dilution effects because these species had much broader leaf blades (and increased growth and biomass) than A. nilotica [32]. Relatively greater accumulation of $\mathrm{Fe}$ as compared to $\mathrm{Mn}$ (high Fe: Mn ratio) in A. nilotica indicated impairing effect of $\mathrm{Ca}$ and $\mathrm{K}$ reducing $\mathrm{Mn}$ concentration, an important constituent (together with $\mathrm{Cu}, \mathrm{Zn}$ and $\mathrm{Fe}$ ) of many enzymes influencing physiological function [33]. Higher plants have also evolved sophisticated antioxidant defense system and glyoxalase system to scavenge the oxidative effects of metals [34]. However, the lowest ratio of Fe : $\mathrm{Mn}$ in E. camaldulensis was an adaptation/defense mechanism through antioxidative systems (superoxide dismutase) for success of this species under high water availability or waterlogged conditions as observed for Populus angustifolia [35, 36].

Increased $\Psi_{l}$ in the seedlings from $\mathrm{T}_{1}$ to $\mathrm{T}_{3}$ was positively influenced by increased level of effluent applicationsoil water availability [37]. However, higher $(P<0.05)$ $\Psi_{l}$ in the seedlings of $\mathrm{T}_{4}$ as compared to the seedlings of $\mathrm{T}_{1}$ treatment was due to two-fold higher water applied to $\mathrm{T}_{4}$. A difference of 1.14 to $1.35 \mathrm{MPa}$ between the lowest and highest $\Psi_{l}$ in the seedlings of E. camaldulensis as compared to those of 0.83 to $1.24 \mathrm{MPa}$ in $A$. nilotica and 0.35 to $0.59 \mathrm{MPa}$ in $D$. sissoo was due to higher $E$ in former than in the latter two species (Table 3). High $\Psi_{l}$ during December and January indicated low water loss or reduced $E$ as a function of low PAR, VPD, low air temperature, and rainfall in January and February, 1999 (Figure 1). However, gradual increase in PAR, VPD, and air temperature with concomitant decrease in $\Psi_{l}$ from January to May in all the three species indicated negative relations between $\Psi_{l}$ and these environmental factors.

4.2. Foliage Nutrients and Gas Exchange. Application of municipal effluent had no toxic effect on $P_{N}, E$, and $g_{S}$ and seedlings grown with municipal effluent irrigation were capable of maintaining efficient photosynthetic activity throughout the growing season. Higher values of these physiological variables in the seedlings grown in $\mathrm{T}_{2}$ and $\mathrm{T}_{3}$ treatments than in the control $\left(\mathrm{T}_{4}\right)$ further suggested that leaf function was unimpaired by the municipal effluent irrigation. Reduced $P_{N}$,
$E$, and $g_{\mathrm{S}}$ together with $\Psi_{l}$ in the seedlings of $\mathrm{T}_{1}$ indicated negative impact of low water supply [38]. Relatively greater increase in these variables during August (monsoon period, Figures 3 and 4) further suggests that the seedlings of this treatment suffered of water stress [39]. A 15\% decrease in $P_{N}$ has been reported in a two-year-old Picea ruben seedlings at water potential averaging $-2.45 \mathrm{MPa}$ [40]. Greater values $(P<0.05)$ of $P_{N}, E$, and $g_{\mathrm{S}}$ in $\mathrm{T}_{4}$ than in $\mathrm{T}_{1}$ seedlings (except in February, 1999, March, May, August, and October, 2000, for $P_{N}$, February and May 1999, and February to June, 2000, for $E$, and May 2000 for $g_{S}$ ) were due to two-fold water applied [41]. Despite of similar level of irrigation (1PET) increased values of the physiological variables in $T_{2}$ as compared to the seedlings of $\mathrm{T}_{4}$ were due to nutritional effects of municipal effluent (Figures 3 and 4). Carswell et al. [42] observed an enhanced rate of electron transport and velocity of carboxylation in Cedrela odorata seedlings at 5\% rate of macro- and micronutrient supply compared to that at $1 \%$ rate. Highest level of irrigation and corresponding increase in water and nutrient supply induced absorption and transport of the nutrients to the seedling resulted in the highest $P_{N}$ and $E$ in the seedlings of $\mathrm{T}_{3}$. This increase in $P_{N}, E$ and $g_{\mathrm{S}}$ was positively related to $\Psi_{l}$ and foliage $\mathrm{N}$ and other nutrients as observed in Pseudotsuga menziesii (Mirb.) Franco. [43]. However, the higher value of $g_{S}$ was not paralleled by increased $P_{N}$ or $E$, which may reflect a partial limitation in foliage biochemistry or leaf structure and varying effects on these physiological variables [44].

Linear/nonlinear increase in $P_{N}$ with nutrient concentrations suggests a close link of photosynthetic capacity with nutrient supply, but simultaneous increases in $E$ and gs (Figure 5) are indicative of rapid growth and biomass production [45]. A decline/saturation, after an initial increase in $P_{N}$ and $E$ with increase in concentrations of $\mathrm{Ca}, \mathrm{Na}$, and $\mathrm{Fe}$, was as a result of the effects of accumulated minerals and limitations due to other nutrients and their ratios $[45,46]$. A reduction in net photosynthetic rate and stomatal conductance due to a toxic effect of $\mathrm{Na}^{+}$has also been reported in Citrus limonia Osbeck and Olea europaea L. [47]. Though increases in $\mathrm{N}, \mathrm{K}, \mathrm{Fe}$, and Mn concentrations were beneficial, but relatively greater increase in $\mathrm{N}$ and $\mathrm{Mn}$ than $\mathrm{K}$ and $\mathrm{Fe}$, respectively, from $\mathrm{T}_{1}$ to $\mathrm{T}_{3}$ seemed to facilitate $P_{N}$ to a greater extent than $E$ evidenced by increased WUE as observed in $D$. sissoo discussed later (Supplementary Figure 1). A 4.0- to 7.1fold variation in $P_{N}$ compared to 2.2- to 4.0-fold variation in $E$ among the months further indicated greater sensitivity of $P_{N}$ to foliage chemistry as well as environmental factors. Increase in $P_{N}, E$, and $g_{\mathrm{S}}$ during monsoon and spring due to reduced VPD, PAR, and air temperature though rainfall suggests the effects of environmental factors in influencing physiological variables. Despite of lower nutrient concentrations except $\mathrm{Mn}$ (highest) higher $P_{N}, E$, and $g_{S}$ in E. camaldulesis were the effects of lower $\Psi_{l}$ and tolerance to Mn because of scavenging system composed of antioxidants as reported for Mntolerant maize (Zea mays L.) [48]. Decrease in the values of these physiological variables during winter (due to plant senescence and reduced VPD and transpiration losses) and summer (due to increase in VPD, PAR, air temperature, desiccating wind velocity, and probably mineral concentrations) 
was similar to that in Pseudotsuga menziesii [49]. Drops in $P_{N}$ and $E$ as a function of high irradiance/temperature through stomatal control have also been reported by Van Assche and Clijsters [50] and Castillo et al. [51].

4.3. Foliage Nutrients and Water Use Efficiency. Nutrient concentration influenced $P_{N}$ and $E$ and thus instantaneous water use efficiency (WUE). A negative relation of nutrients concentration with WUE suggested impaired effects of $\mathrm{K}, \mathrm{Ca}, \mathrm{Na}$, and $\mathrm{Zn}$ on $E$ than on $P_{N}$. Increase in $P_{N}$ was associated with increase in $E$ and $g_{\mathrm{S}}$ from $\mathrm{T}_{1}$ to $\mathrm{T}_{3}$ treatments, but greater increase in $E$ as compared to $P_{N}$ due to increased water and nutrient supply from $\mathrm{T}_{1}$ to $\mathrm{T}_{3}$ impaired WUE. Ewers et al. [52] observed an increase in transpiration rate in irrigated trees, relative to unirrigated trees by the effect of irrigation combined with fertilization. Low WUE in municipal effluent irrigated seedlings as compared to control ( $\mathrm{T}_{4}$ treatment) was due increased water availability which enhanced $E$ to a greater extent (increased by $46 \%$ in $\mathrm{T}_{2}$ and $85 \%$ in $\mathrm{T}_{3}$ ) than $P_{N}$ (increased by $34 \%$ in $\mathrm{T}_{2}$ and $66 \%$ in $\left.\mathrm{T}_{3}\right)$. Higher $(P<0.01)$ WUE in $D$. sissoo than the other species in most of the months (Figure 4(b)) was due to enhanced foliage $N$ and $P$ concentrations with greater positive influence on $P_{N}$ than on $E$. Thus $D$. sissoo was able to maintain high rates of $P_{N}$ with relatively low $g_{\mathrm{S}}$ and $E$ is considered to be tolerant to low moisture availability and has high WUE [50]. An inverse relation between $\mathrm{K}: \mathrm{N}$ ratio and WUE (Table 3; Figure 5) also suggests foliar chemistry regulated variations in $E$ and $P_{N}$. Lowest WUE in $A$. nilotica was due to relatively greater concentrations (than in other species) of basic cations together with $\mathrm{Fe}$ and $\mathrm{Zn}$ and lesser concentrations of $\mathrm{P}$ and $\mathrm{Mn}$ influencing $P_{N} / E$ ratio. This type of species-specific response in WUE had also been observed in Vismia japurensis, Bellucia grossularioides, and Laetia procera when treated with $\mathrm{P}, \mathrm{Ca}$, and gypsum [53]. After initial increase, a decrease in WUE with increase in ratios of $\mathrm{Mg}: \mathrm{Mn}, \mathrm{Fe}: \mathrm{Mn}$, and $\mathrm{Zn}$ : Mn suggested an adverse effect of $\mathrm{Mg}, \mathrm{Fe}$, and $\mathrm{Zn}$ on WUE at enhanced concentrations. It seemed that Mn played a part in stabilizing mineral ratio to maintain up right $P_{N}: E$ ratio (WUE).

\section{Conclusions and Recommendation}

Irrigating tree seedlings with municipal effluent showed positive influence on nutrient accumulation and physiological functions, that is, $\Psi_{l}, P_{N}, E$, and $g_{S}$. Enhanced $P_{N}$ together with $E$ and $g_{S}$ with increased water and nutrient from $\mathrm{T}_{1}$ to $\mathrm{T}_{3}$ indicated a fast growth in the tree seedlings. Increase in physiological functions in $\mathrm{T}_{2}$ as compared to $\mathrm{T}_{4}$ was the nutrient effects, whereas their increase in $\mathrm{T}_{4}$ than in $\mathrm{T}_{1}$ was the effect of water. Relatively higher and lower concentrations of basic cations and Fe influenced gas exchange negatively in A. nilotica and positively in E. camaldulensis, respectively, affecting WUE. A positive effect of $\mathrm{N}$ and $\mathrm{P}$ on net photosynthesis and that of $\mathrm{K}$ on transpiration rate influenced WUE in these seedlings. D. sissoo was efficient water user by maintaining up right ratio between $P_{N}$ and $E$ by accumulating higher $\mathrm{N}$ and $\mathrm{P}$, and lower $\mathrm{Mg}, \mathrm{Na}$, and Fe concentrations than other mineral nutrients. Adequate concentration of $\mathrm{Mg}, \mathrm{Na}$, Fe and $\mathrm{Zn}$ enhanced physiological functions, but their higher concentrations adversely affected gas exchange and WUE. Conclusively, higher nutrient accumulation and low WUE in A. nilotica seedling were adaptations towards higher nutrient load and this species can safely be categorized as best soil ameliorator [32]. D. sissoo maintained relatively greater $P_{N}$ and lesser $E$ (a characteristic of efficient water user). E. camaldulensis maintained higher gas exchange by reducing concentration of basic cations and stabilizing $\mathrm{Fe}: \mathrm{Mn}$ and $\mathrm{Mg}: \mathrm{Mn}$ ratios and can be better species for long term disposal of municipal effluent.

\section{Conflict of Interests}

The authors declare that there is no conflict of interests regarding the publication of this paper.

\section{Acknowledgment}

The authors are thankful to the Director of Arid Forest Research Institute, Jodhpur, for providing necessary facilities.

\section{References}

[1] B. Robinson, C. Russell, M. Hedley, and B. Clothier, "Cadmium adsorption by rhizobacteria: implications for New Zealand pastureland," Agriculture, Ecosystems and Environment, vol. 87, no. 3, pp. 315-321, 2001.

[2] F. I. Khan, T. Husain, and R. Hejazi, "An overview and analysis of site remediation technologies," Journal of Environmental Management, vol. 71, no. 2, pp. 95-122, 2004.

[3] S. Cenkci, İ. H. Ciğerci, M. Yıldız, C. Özay, A. Bozdağ, and H. Terzi, "Lead contamination reduces chlorophyll biosynthesis and genomic template stability in Brassica rapa L.," Environmental and Experimental Botany, vol. 67, no. 3, pp. 467-473, 2010.

[4] R. R. Brooks, Plants that Hyperaccumulate Heavy Metals, CAB International, Wallingford, UK, 1998.

[5] H. Sarma, "Metal hyperaccumulation in plants: a review focusing on phytoremediation technology," Journal of Environmental Science and Technology, vol. 4, no. 2, pp. 118-138, 2011.

[6] C. Huang, S. J. Barker, P. Langridge, F. W. Smith, and R. D. Graham, "Zinc deficiency up-regulates expression of high-affinity phosphate transporter genes in both phosphate-sufficient and -deficient barley roots," Plant Physiology, vol. 124, no. 1, pp. 415422, 2000.

[7] J. T. Ward, B. Lahner, E. Yakubova, D. E. Salt, and K. G. Raghothama, "The effect of iron on the primary root elongation of Arabidopsis during phosphate deficiency," Plant Physiology, vol. 147, no. 3, pp. 1181-1191, 2008.

[8] A. Jain, M. D. Poling, A. P. Smith et al., "Variations in the composition of gelling agents affect morphophysiological and molecular responses to deficiencies of phosphate and other nutrients," Plant Physiology, vol. 150, no. 2, pp. 1033-1049, 2009.

[9] A. S. Walcroft, D. Whitehead, W. B. Silvester, and F. M. Kelliher, "The response of photosynthetic model parameters to temperature and nitrogen concentration in Pinus radiata D. Don," Plant, Cell and Environment, vol. 20, no. 11, pp. 1338-1348, 1997. 
[10] J. S. Pereira, M. M. Chaves, F. Fonseca et al., "Photosynthetic capacity of leaves of Eucalyptus globulus (Labil.) growing in the field with different nutrient and water supplies," Tree Physiology, vol. 11, pp. 381-389, 1991.

[11] V. R. Nenova, "Growth and photosynthesis of pea plants under different iron supply," Acta Physiologiae Plantarum, vol. 31, no. 2, pp. 385-391, 2009.

[12] Z.-G. Shen, X.-D. Li, C.-C. Wang, H.-M. Chen, and H. Chua, "Lead phytoextraction from contaminated soil with highbiomass plant species," Journal of Environmental Quality, vol. 31, no. 6, pp. 1893-1900, 2002.

[13] R. Mata-González, R. E. Sosebee, and C. Wan, "Physiological impacts of biosolids application in desert grasses," Environmental and Experimental Botany, vol. 48, no. 2, pp. 139-148, 2002.

[14] G. Singh and M. Bhati, "Growth, biomass production and nutrient composition of Eucalyptus camaldulensis seedlings irrigated with municipal effluent in loamy sand soil of Indian desert," Journal of Plant Nutrition, vol. 26, no. 12, pp. 2469-2488, 2003.

[15] G. Singh and M. Bhati, "Mineral accumulation, growth, and physiological functions in Dalbergia sissoo seedlings irrigated with different effluents," Journal of Environmental Science and Health A, vol. 38, no. 11, pp. 2679-2695, 2003.

[16] OMA, Official Methods of Analysis, Association of Official Analytical Chemists, Arlington, Va, USA, 15th edition, 1990.

[17] M. L. Jackson, Soil Chemical Analysis, Prentice Hall of India, New Delhi, India, 1973.

[18] K. N. Rao, C. J. George, K. S. Ramasastri et al., "Climatic classification of India," Scientific Report 158, India Meteorological Department, New Delhi, India, 1971.

[19] E. Stibbe, "Soil moisture depletion in summer by an eucalyptus grove in a desert area," Agro-Ecosystems, vol. 2, no. 2, pp. 117-126, 1975.

[20] M. L. Sharma, "Evapotranspiration from a eucalyptus community," Agricultural Water Management, vol. 8, no. 1-3, pp. 41-56, 1984.

[21] R. G. Allen, M. E. Jensen, J. L. Wright et al., "Operational estimates of reference evapotranspiration," Agronomy Journal, vol. 81, pp. 650-662, 1989.

[22] A. F. Heuperman, A. S. Kapoor, H. W. Denecke et al., "Biodrainage: principle, experiences and application," in Proceedings of the International Programme for Technology and Research in Irrigation and Drainage (IPTRID '02), p. 15, FAO, Rome, 2002.

[23] E. C. Campbell, G. S. Campbell, and W. K. Barlow, "A dewpoint hygrometer for water potential measurement," Agricultural Meteorology, vol. 12, pp. 113-121, 1973.

[24] S. S. Shapiro and M. B. Wilk, "An analysis of variance test for normality: Complete samples," Biometrika, vol. 52, pp. 591-611, 1965.

[25] H. Levene, "Robust tests for equality of variances," in Contributions to Probability and Statistics, pp. 278-292, Stanford University, Palo Alto, Calif, USA, 1960.

[26] D. R. R. Malkanthi, M. Moritsugu, and K. Yokoyama, "Effects of low $\mathrm{pH}$ and $\mathrm{Al}$ on absorption and translocation of some essential nutrients in excised barley roots," Soil Science \& Plant Nutrition, vol. 41, no. 2, pp. 253-262, 1995.

[27] P. Drechsel and W. Zech, "Foliar nutrient levels of broad-leaved tropical trees: a tabular review," Plant and Soil, vol. 131, no. 1, pp. 29-46, 1991.
[28] N. E. Marcar, "Fodder values of salt tolerant Australian Acacias," in Proceedings of the International Workshop on Nitrogen Fixing Trees for Fodder (IWNFTF '95), pp. 20-25, Pune, India, 1995.

[29] . Bargali K and SS. Bargali, "Acacia nilotica: a multipurpose leguminous plant," Nature and Science, vol. 7, pp. 11-19, 2009.

[30] S. M. Reichman, C. J. Asher, D. R. Mulligan, and N. W. Menzies, "Seedling responses of three Australian tree species to toxic concentrations of zinc in solution culture," Plant and Soil, vol. 235 , no. 2, pp. 151-158, 2001.

[31] S. M. Reichman, N. W. Menzies, C. J. Asher, and D. R. Mulligan, "Seedling responses of four Australian tree species to toxic concentrations of manganese in solution culture," Plant and Soil, vol. 258, no. 1-2, pp. 341-350, 2004.

[32] M. U. Shirazi, M. A. Khan, M. Ali et al., "Growth performance and nutrient contents of some salt tolerant multipurpose tree species growing under saline environment," Pakistan Journal of Botany, vol. 38, no. 5, pp. 1381-1388, 2006.

[33] E. J. Hewitt, "The role of mineral elements in the activity of plant enzyme systems," Encyclopedia of Plant Physiology, vol. 4, pp. 427-481, 1958.

[34] M. A. Hossain, P. Piyatida, J. A. T. da Silva, and M. Fujita, "Molecular mechanism of heavy metal toxicity and tolerance in plants: central role of glutathione in detoxification of reactive oxygen species and methylglyoxal and in heavy metal chelation," Journal of Botany, vol. 2012, Article ID 872875, 37 pages, 2012.

[35] S. Alam, F. Akiha, S. Kamei, S. M. I. Huq, and S. Kawai, "Mechanism of potassium alleviation of manganese phytotoxicity in barley," Journal of Plant Nutrition, vol. 28, no. 5, pp. 889-901, 2005.

[36] K. A. Barrick and M. G. Noble, "The iron and manganese status of seven upper montane tree species in Colorado, USA, following long-term waterlogging," Journal of Ecology, vol. 81, no. 3, pp. 523-531, 1993.

[37] R. Tognetti, A. Longobucco, F. Miglietta, and A. Raschi, "Water relations, stomatal response and transpiration of Quercus pubescerts trees during summer in a mediterranean carbon dioxide spring," Tree Physiology, vol. 19, no. 4-5, pp. 261-270, 1999.

[38] H. Schnabl and H. Ziegler, "The mechanism of stomatal movement in Allium cepa L.," Planta, vol. 136, no. 1, pp. 37-43, 1977.

[39] N. Mohanty and I. Vass, "Impairment of PSII activity at the level of secondary quinone electron acceptors in chloroplast treated with $\mathrm{Co}^{+2}, \mathrm{Zn}^{+2}, \mathrm{Ni}^{+2}$ and ions," Physiology Plant, vol. 76, pp. 386-390, 1989.

[40] H. Seiler and B. H. Cazel, "Influence of water stress on the physiology and growth of red spruce seedlings," Tree Physiology, vol. 6, no. 1, pp. 69-77, 1990.

[41] B. Singh and G. Singh, "Biomass partitioning and gas exchange in Dalbergia sissoo seedlings under water stress," Photosynthetica, vol. 41, no. 3, pp. 407-414, 2003.

[42] C. Carswell, J. Grace, M. E. Lucas, and P. G. Jarvis, "Interaction of nutrient limitation and elevated $\mathrm{CO}_{2}$ concentration on carbon assimilation of a tropical tree seedling (Cedrela odorata)," Tree Physiology, vol. 20, no. 14, pp. 977-986, 2000.

[43] A. K. Mitchell and T. M. Hinkley, "Effects of foliar nitrogen concentration on photosynthesis and water use efficiency in Douglas-fir," Tree Physiology, vol. 12, pp. 403-410, 1993.

[44] R. Tognetti, L. Sebastiani, and A. Minnocci, "Gas exchange and foliage characteristics of two poplar clones grown in soil amended with industrial waste," Tree Physiology, vol. 24, no. 1, pp. 75-82, 2004. 
[45] G. Singh and M. Bhati, "Changing effluent chemistry affect survival, growth and physiological function of Acacia nilotica seedlings in northwestern region of India," Environmentalist, vol. 28 , no. 3, pp. 175-184, 2008.

[46] G. Rubio, J. Zhu, and J. P. Lynch, "A critical test of the two prevailing theories of plant response to nutrient availability," The American Journal of Botany, vol. 90, no. 1, pp. 143-152, 2003.

[47] J. C. Melgar, J. P. Syvertsen, V. Martínez, and F. García-Sánchez, "Leaf gas exchange, water relations, nutrient content and growth in citrus and olive seedlings under salinity," Biologia Plantarum, vol. 52, no. 2, pp. 385-390, 2008.

[48] S. Doncheva, C. Poschenrieder, Z. Stoyanova, K. Georgieva, M. Velichkova, and J. Barceló, "Silicon amelioration of manganese toxicity in Mn-sensitive and Mn-tolerant maize varieties," Environmental and Experimental Botany, vol. 65, no. 2-3, pp. 189-197, 2009.

[49] F. C. Meinzer, "The effect of light on stomatal control of gas exchange in Douglas fir (Pseudotsuga menziesii) saplings," Oecologia, vol. 54, no. 2, pp. 270-274, 1982.

[50] F. van Assche and H. Clijsters, "Inhibition of photosynthesis in Phaseolus vulgaris by treatment with toxic concentrations of zinc: effects on electron transport and photophosphorylation," Physiologia Plantarum, vol. 66, no. 4, pp. 717-721, 1986.

[51] J. M. Castillo, A. E. Rubio Casal, C. J. Luque, T. Luque, and M. E. Figueroa, "Comparative field summer stress of three tree species co-occurring in Mediterranean coastal dunes," Photosynthetica, vol. 40, no. 1, pp. 49-56, 2002.

[52] B. E. Ewers, R. Oren, T. J. Albaugh, and P. M. Dougherty, "Carryover effects of water and nutrient supply on water use of Pinus taeda," Ecological Applications, vol. 9, no. 2, pp. 513-525, 1999.

[53] C. C. Ma, Y. B. Gao, H. Y. Guo, and J. L. Wang, "Photosynthesis, transpiration, and water use efficiency of Caragana microphylla, C. intermedia, and C. korshinskii," Photosynthetica, vol. 42, no. 1, pp. 65-70, 2004. 

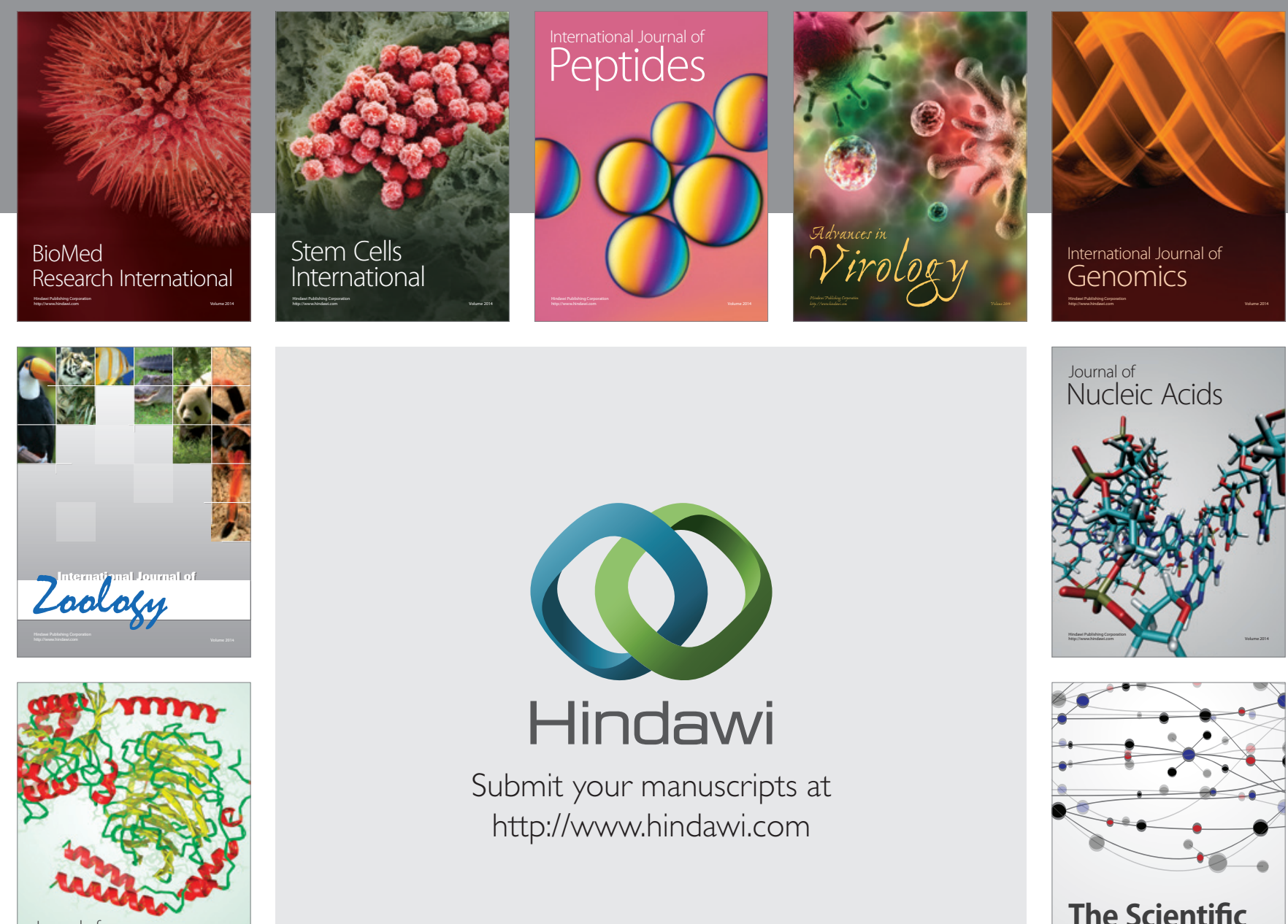

Submit your manuscripts at

http://www.hindawi.com

Journal of
Signal Transduction
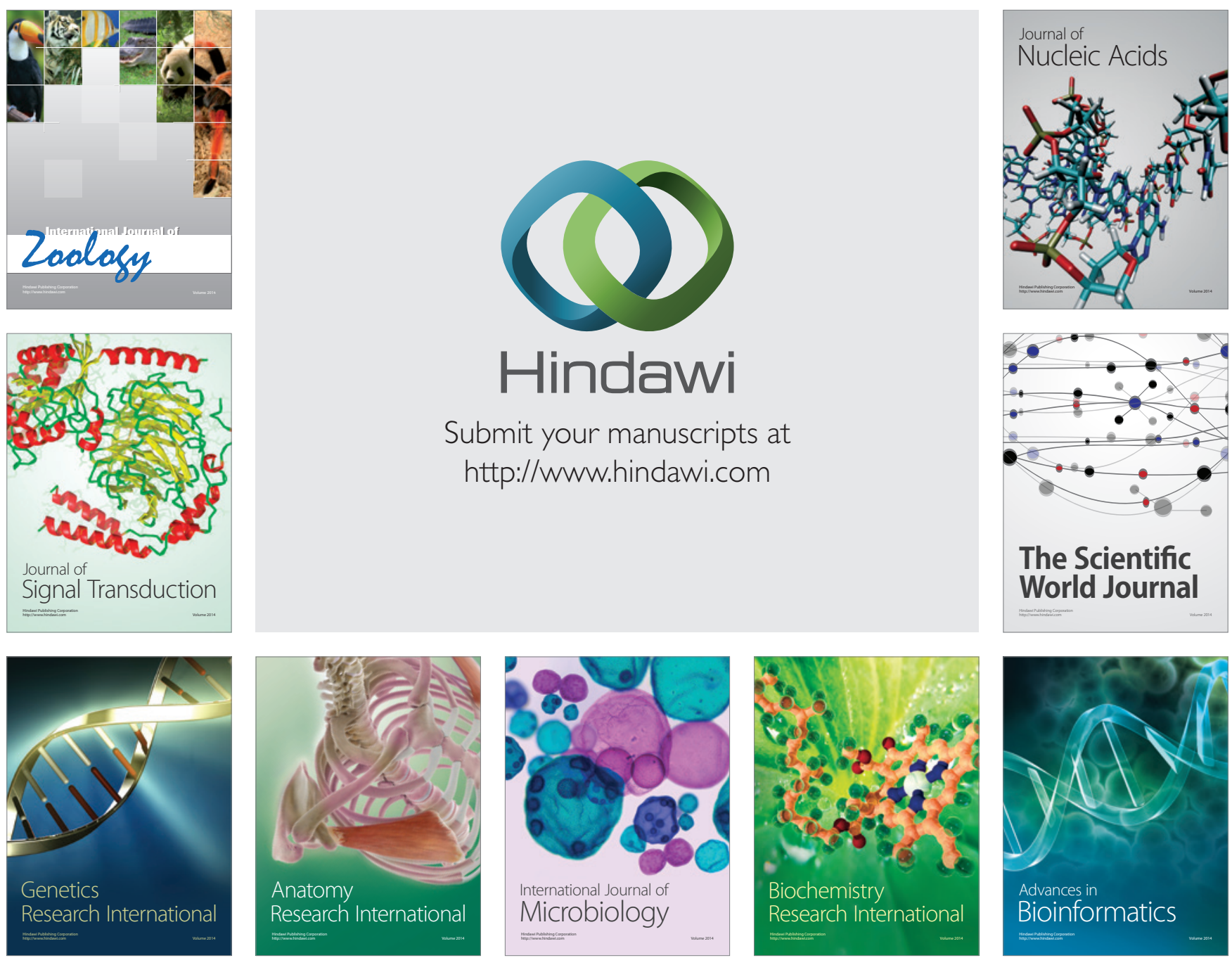

The Scientific World Journal
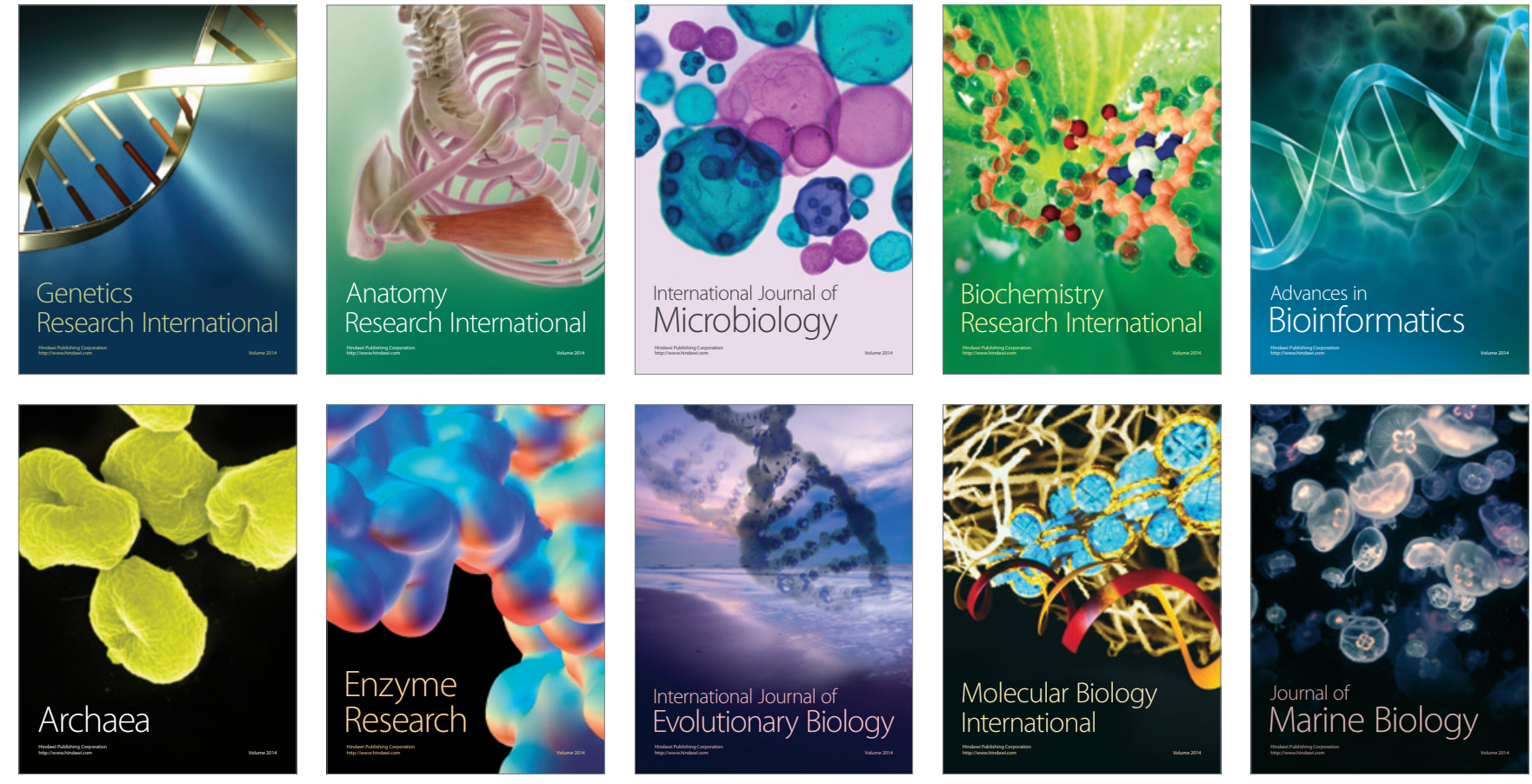